Yerbilimleri, 2021, 42 (1), 144-178, DOI: 10.17924/yerbilimleri.899989

Hacettepe Üniversitesi Yerbilimleri Uygulama ve Araştırma Merkezi Bülteni

Bulletin of the Earth Sciences Application and Research Centre of Hacettepe University

\title{
Eklenik Sapma Yaklaşımı ile Türetilen Yağış-Seviye İlişkisinden Yeraltısuyu Beslenimi Tahmin Modeli: Gazipaşa (Antalya) Ovası Akiferi Örneği
}

Groundwater Recharge Estimation Model from Rainfall-Groundwater Level Relationship Derived by Cumulative Departure Model: Case of Gazipaşa (Antalya) Plain Aquifer

\author{
MEHMET EKMEKÇi ${ }^{1,2^{*}}$, ŞÜKRAN AÇIKEL ${ }^{1,2}$ \\ ${ }^{1}$ Hacettepe Üniv., Jeol. Müh. Böl., Hidrojeoloji Prog., 06800, Beytepe, ANKARA \\ ${ }^{2}$ Hacettepe Üniv., Uluslararası Karst Su Kayn. Uyg. ve Araş. Merkezi., 06800, Beytepe, ANKARA
}

Geliş (received): 22 Mart (March) 2021 Kabul (accepted): 21 Nisan (April) 2021

Öz

Yeraltısuyu beslenimi, su kaynakları potansiyelinin hesaplanmasında ihtiyaç duyulan temel parametrelerden biridir. Yeraltısuyu beslenme miktarının tahmin edilmesinde çeşitli yöntemler uygulanmakla birlikte, süzülme ve vadoz zon hidrolojisinin karmaşıklığı nedeniyle her yöntemin olumlu ve olumsuz yönleri bulunmaktadır. Karmaşık teoriye dayanmayan, temsil ediciliği düşük ve elde edilmesi zor parametreler gerektirmeyen, sonuçları görece yüksek güvenirliğe sahip, kolay uygulanabilir bir yöntem arayışı halen sürmektedir. Yeraltısuyu seviyesinde meydana gelen yükselimin yağıştan süzülen suyun doygun zona ulaşması sonucu olduğu varsayımıyla, yağışların eklenik etkilerinden yola çıkılarak beslenme miktarının tahmin edilmesi yaklaşımı, görece az sayıda veri gerektirmekte ve kolay uygulanabilirken, aynı zamanda belirli bir düzeyde güvenilir sonuçlar vermektedir. Bu çalışmada, ortalamadan eklenik sapma yaklaşımının kuramsal temelleri açıklanmış, yöntem Antalya-Gazipaşa Ovası akiferine uygulanmıştır.

https://doi.org/10.17824/yerbilimleri.899989

M. EKMEKÇi, ekmekci@hacettepe.edu.tr

${ }^{1}$ Hacettepe Üniv., Jeol. Müh. Böl., Hidrojeoloji Prog., 06800, Beytepe, ANKARA ORCID 0000-0002-6729-7457

${ }^{2}$ Hacettepe Üniv., Jeol. Müh. Böl., Hidrojeoloji Prog., 06800, Beytepe, ANKARA ORCID 0000-0001-9534-4380 
Yapılan analizler sonucunda, gözlenen yeraltısuyu seviyelerinin yüksek determinasyon katsayılarıyla türetilmesi mümkün olmuştur. Ayrıca yöntemle, yeraltısuyu seviye değişimine neden olan, akarsu yatağından sızma ve pompaj gibi dış etkileri analiz etmek mümkün olmuş, ova akiferinin açık bir sistem yapısında olduğu ortaya konmuştur.

Anahtar Kelimeler: Beslenme, eklenik sapma, Gazipaşa ovası, yağış, yeraltısuyu.

\section{Abstract}

Groundwater recharge is one of the basic parameters required in water resources potential calculations. There are several methods applied to estimate groundwater recharge, however, every method has its own advantages and disadvantages, due to the fact that the theory of infiltration and the vadose zone hydrology is highly complex. Search for a method based on less complex theory, which requires readily available and representative parameters, and gives reliable results is still of interest. Groundwater recharge estimation based on the assumption that the groundwater level in the saturated zone rises as a result of the cumulative rainfall may well meet these expectations. It requires less data, easy to calculate and gives relatively reliable results. In this paper, following an explanation of the theoretical basis, the method is applied to Antalya-Gazipaşa plain aquifer. The analyses have revealed that the method can produce the deviations in observed groundwater based on the cumulative rainfall departure, with high coefficients of determination. The method was also used to analyse the external effects, such as percolation from river beds and groundwater pumping, on the deviations of groundwater levels from the average, which suggests that the plain aquifer constitutes an open system.

Keywords: Recharge, cumulative departure, Gazipaşa Plain, rainfall, groundwater.

\section{GíRiş}

Yeraltısuyu besleniminin sağlıklı bir şekilde belirlenmesi, hidrojeoloji mühendisliğinin en sorunlu alanlarından birini oluşturmaktadır. Bu nedenle, hidrojeoloji literatüründe yeraltısuyu beslenimine ilişkin çok farklı yaklaşım, teknik ve yöntemle karşılaşılmaktadır (Simmers, 1988; Sharma, 1989; Lerner vd., 1990; Gieske, 1992; Bredenkamp vd., 1995; Kinzelbach vd., 2002; Beekman ve Xu, 2003; Şen, 2019). 
Her yaklaşımın kendine özgü olumlu ve olumsuz yönleri bulunmakta, farklı yeraltısuyu sistemlerinde beslenme miktarını aynı düzeyde doğrulukla veren, görece kolay uygulanabilir genel bir yaklaşım veya yöntem bulunmamaktadır. Yağıştan süzülerek doygun zona ulaşan su miktarı olarak tanımlanabilecek olan "beslenme", doğal olarak akiferdeki yeraltısuyu seviyesinde yükselime neden olur.

Doğal koşullar altında yeraltısuyu seviyesindeki değişimler akiferin doğal beslenimi ve boşalımı ile ilgilidir. Akiferi oluşturan malzemenin depolama katsayısı (serbest akiferler için özgül verim) bilindiğinde belirli bir zaman aralığı için akifere yağıştan gelen beslenme miktarı, söz konusu zaman aralığında yeraltısuyu seviyesinde meydana gelen değişim kullanılarak hesaplanabilir (Freeze ve Cherry, 1979; Bear, 1979, Todd, 1980). Bu kapsamda, "akiferin birim yüzey alanında, piyezometrik seviyede birim değişime neden olan su hacmi" olarak ifade edilen depolama katsayısı tanımının matematiksel eşitliklerinden yararlanılabilir. Doğal koşullarda, bir akiferde belirli bir $\Delta t$ süresinde meydana gelen yeraltısuyu seviye değişiminden beslenme miktarı aşağıda verilen eşitliklerden belirlenebilir.

$\Delta h=\frac{\Delta V}{A \cdot S_{y}}$

Burada,

$\Delta h$ : yeraltısuyu seviyesindeki değișim, $(L)$

$\Delta V$ : akiferde doygun zona ulaşan yağış miktarı, $\left(L^{3}\right)$

$A$ : akiferin alanı, $\left(L^{2}\right)$

$S_{y}$ : özgül verim, (-)

Yağışın belirli bir $\Delta t$ süresinde doygun zona ulaşan kısmı beslenme $(\operatorname{Re}=\Delta V)$ olarak tanımlandığına göre, bu miktar eşitlik (1)'in aşağıdaki şekilde düzenlenmesini gerektirir. $\Delta t$ süresi günlük, aylık, yıllık veya daha uzun olabilir. Beslenme, bu nedenle $\mathrm{L} / \mathrm{T}$ boyutunda ve genellikle $\mathrm{mm} /$ ay veya $\mathrm{mm} / \mathrm{y} ı \mathrm{l}$ biriminde ifade edilir.

$R e=\Delta h \cdot A \cdot S_{y}$

$\mathrm{Bu}$ yaklaşım görece kolay uygulanabilir görünse de, uygulamada önemli belirsizliklere neden olan güçlüklerle karşılaşılır. Akiferi temsil eden bir depolama 
katsayısı/özgül verim değerinin elde edilmesi ile yeraltısuyu seviyesindeki değişime neden olan yağışların belirlenmesi karşılaşılan başlıca güçlüklerdir.

Belirli bir zaman aralığında meydana gelen seviye değişimi ile bu zaman aralığında akiferin beslenme alanına düşen yağış miktarı arasında genellikle doğrudan bir korelasyon söz konusu olmamaktadır. Akiferin beslenme alanına düşen yağışın doygun zona ulaşması belirli bir süre aldığından, yağışın yeraltısuyu seviyesine etkisi belirli bir gecikmeyle gerçekleşir. Öte yandan, bu gecikmeli etki nedeniyle ard arda meydana gelen yağışların eklenik etkilerinin sözkonusu olacağı açıktır. Örneğin, yeraltısuyu seviyesindeki değişimlerin ortalama yağıştan eklenik sapma ile ilişkilendirilmesi çalışmaları 1930'lu yıllara kadar gitmektedir. Wenzel (1936) ortalama yağıştan eklenik sapma ile yeraltısuyu seviyeleri arasında ilişki kurmaya çalışmış, Jacob (1944) ise geçmiş dönemlerdeki yağışların etkisini dikkate almaya yönelik olarak hareketli ortalama yaklaşımını uygulamıştır.

Türkiye'de Korkmaz (1978), boşalım kotuna göre seviye değişimleri ile yıllık yağışlar ve ortalama yağıştan eklenik sapma ile korelasyon analizleri gerçekleştirmiş, akiferlerin yıllık yağışların etkisi altında olanlar ile eklenik yağışların etkisi altında olanlar şeklinde sınıflanabileceğini ileri sürmüştür. Yağışlarla seviyeler arasındaki ilişkileri, yağışlı aylar ile kurak aylar için farklı regresyon eşitlikleri ile tanımlayabilmiştir. Bununla birlikte, yeraltısuyu seviyelerini yağışlardan itibaren yeniden türetebilecek bir ilişki ortaya koymamıştır.

Dolayısıyla, Korkmaz (1978)'de tanımlanan yöntemin sağlıklı bir sonuç verebilmesi, akifer malzemesinin özgül veriminin değeri ile birlikte yeraltısuyu seviyesini etkileyen yağışların doygun zona ulaşma süresi (gecikme) ve eklenik etki yaratan geçmiş yağış dönemi bilgilerini gerektirir. Akiferi besleyen yağışlar ile aynı dönemi kapsayan ve aynı zaman ölçeğinde elde edilmiş yeraltısuyu seviyelerine ait zaman serilerinin karşılaştırılarak incelenmesiyle bu kritik bilgiler belirli ölçüde elde edilebilir. Doğal ortamlarda akiferler kapalı sistemlerden çok, yüzey sularıyla etkileşim içinde olan açık sistemler oluştururlar. Bu nedenle yağış-seviye ilişkilerinde, yeraltısuyu seviyesinin değişiminde etkili olabilecek doğal yapılara (akarsu, kaynak vb.) yakınlık veya pompaj ve benzeri sistemlerle insanlar tarafından yeraltısuyu çekimi yapılan üretim kuyularının etki alanı içinde bulunma koşullarının dikkate alınması gerekir.

$\mathrm{Bu}$ çalışmada, yeraltısuyu besleniminin eşitlik (2) yardımıyla hesaplanabilmesi temelinde yer alan yağış-seviye ilişkilerinin belirlenmesine yönelik eklenik sapma 
yöntemi Botha ve Bredenkamp, 1993; Bredenkamp vd., 1995; Xu ve Van Tonder, 2001; Sun vd., 2013 tarafından yapılan çalışmalardan yararlanılarak tanımlanmış ve yöntem Antalya Gazipaşa Ovası alüvyon akiferine uygulanmıştır. Gazipaşa Ovası akiferinin serbest akifer olması, ovada alanı temsil edebilen yağış istasyonu bulunması, ovada yeraltısuyu kullanımının sınırı olması ve hidrojeolojik konumları farklı iki gözlem kuyusuna ait verilerin varlığı, bu akiferin uygulama alanı olarak seçilmesinin temel nedenlerinin başında gelmektedir.

\section{Yöntemin Kuramsal Temelleri}

Yeraltısuyu çekiminin olmadığı doğal koşullarda bir akiferde beslenme ile boşalım arasında bir dinamik dengeye ulaşıldığı kabul edilir. Bu kabule dayanarak yeraltısuyu seviyesinde değişimin beslenimi ve boşalımı denetleyen bileşenlere bağlanabileceği ileri sürülebilir ve ortalama yağıştan eklenik sapma yaklaşımında "denge koşullarında akiferin ortalama beslenimi akiferden oluşan ortalama kayıplar kadardır" şeklinde ifade edilebilir. Bu yaklaşımı temel alan Jacob (1944), uzun yıllar ortalamasından sapma yerine yağışın hareketli ortalamasından sapmayı kullanmışır. Bu şekilde, herhangi bir " $\mathrm{t}$ " anındaki beslenme üzerinde uzak geçmişte oluşan yağışlarının etkileri ilerleyen zaman içinde gittikçe azaltımış, aynı zamanda " $\mathrm{t}$ " anından sonraki yağışların da etkisinin herhangi bir "t" anındaki beslenmeye olan etkisi de ortadan kalkmış olmaktadır. Bu şekilde, yağış serisinin beslenmeye olan etkileri daha gerçekçi bir şekilde yansıtılmıştır.

Pompaj etkisinin bulunmadığı işletme öncesi koşullarda, yeraltısuyu seviyesindeki dalgalanmalar ile ortalama yağıştan eklenik sapma (OYES) arasında genellikle görsel bir uyum gözlenebilmektedir. Yeraltısuyu işletmelerinin bulunduğu ancak pompaj etkisinin sınırlı olduğu akiferlerde de OYES ile yeraltısuyu seviyesi (YASS) arasında belirgin bir uyum gözlenebilmektedir. Bu ilişkiye örnek olarak Niğde Misli Ovası akiferinde bulunan 34798 nolu DSi gözlem kuyusunda kaydedilen yeraltısuyu seviyeleri Şekil 1'de verilmiştir.

Botha ve Bredenkamp (1993); Bredenkamp vd., (1995); Xu Y. ve Van Tonder (2001) ve Sun vd., (2013), OYES yöntemini, pompaj etkisinin de dikkate alındığı durumlara uyarlayarak Güney Afrika'daki yarı kurak-kurak bölgelerde yer alan serbest akiferler için başarılı bir şekilde uygulamışlardır. 


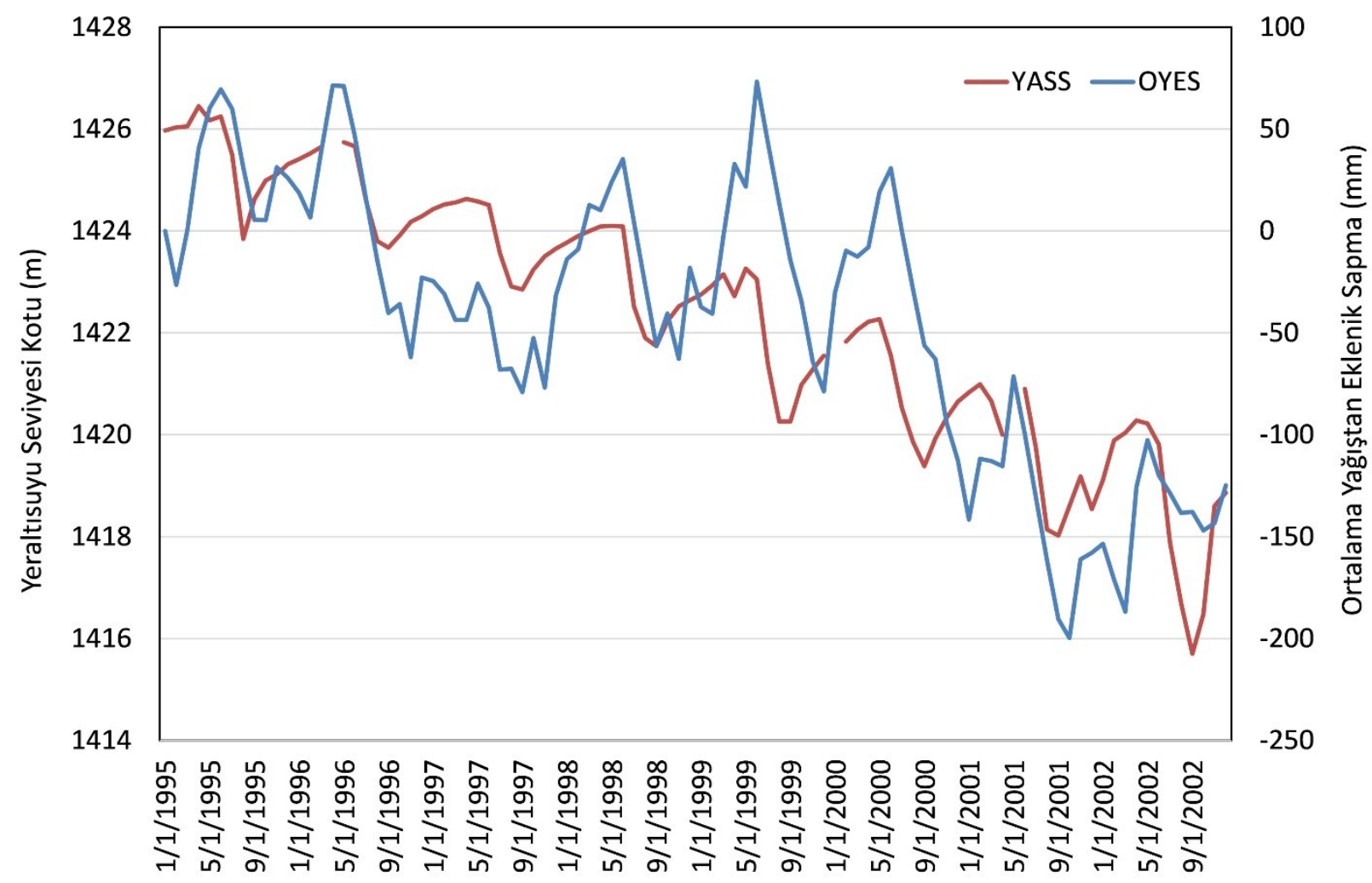

Şekil 1. Yeraltısuyu seviyeleri değişimi (YASS) ile Ortalama Yağıştan Eklenik Sapma (OYES) arasındaki görsel uyuma bir örnek: Niğde Misli Ovası Akiferi 34798 nolu gözlem kuyusu.

Figure 1. An example for the visual correlation between the deviations in groundwater levels (YASS) and the cumulative rainfall departure (OYES): well no 34798 in Niğde Misli Plain Aquifer.

Yeraltısuyu seviyesindeki dalgalanmaların, doğal kararlı koşullarda yağıştan beslenmeyle bağlantılı olması gerektiğini varsayan Botha ve Bredenkamp (1993), OYES ile beslenme arasındaki ilişkiyi aşağıdaki yaklaşım çerçevesinde kurmuş, Lichtenburg akiferinde uygulamış ve OYES ile YASS değişimi arasındaki fonksiyonel ilişkiden yola çıkılarak doygun zondaki hacim değişimine, buradan da beslenme miktarına ulaşılabildiğini göstermişlerdir.

Bredenkamp vd., (1995)'e göre, herhangi bir t anındaki yeraltısuyu seviyesi (h) ve t anındaki ortalama yağıştan eklenik sapma (OYES) arasındaki fonksiyonel ilişki, eşitlik (3), eşitlik (4) ve eşitlik (5) ile;

$h=f(O Y E S)$

doygun zondaki hacimsel değişim (V) cinsinden

$V=f(O Y E S)$ 
ve bir regresyon eşitliği olarak

$V=c . O Y E S+d$

şeklinde yazılabilir. Bir doğru denklemini temsil eden regresyon eşitliğinde c, doğrunun eğimi (orantı katsayısı) ve d, doğrunun apsisi kestiği nokta, diğer bir ifadeyle doğrusal regresyon sabitidir.

Herhangi bir t anındaki OYES ise tanımı gereği,

$\mathrm{t}=1$ için $O Y E S_{1}=O Y E S_{0}+P_{1}-P_{\text {ort }}$

$\mathrm{t}=2$ için $O Y E S_{2}=O Y E S_{1}+P_{2}-P_{\text {ort }}=P_{1}+P_{2}-2 P_{\text {ort }}+O Y E S_{0}$

$\mathrm{t}=3$ için $\quad O Y E S_{3}=O Y E S_{2}+P_{3}-P_{\text {ort }}=P_{1}+P_{2}+P_{3}-3 P_{\text {ort }}+O Y E S_{0}$

genelleştirilirse eşitlik (6)

$O Y E S_{i}=\sum_{j=1}^{j=i} P_{j}-i . P_{m}+O Y E S_{0}$

şeklinde elde edilir.

Burada,

$P_{j}=$ j dönemi yağışı

Port= ortalama yağış, ve

ortalama koşullar için k= 1 olmak üzere Pm = k.Port olarak tanımlanmıştır.

Bu eşitlikte, j beslenme dönemi (kısa hafıza dönemi, $m$, bu çalışmada $m=3$ ay); i, veri serisi uzunluğu (uzun hafıza dönemi, $n$, bu çalışmada $n=26$ ay), Pm ise doğal koşullar dışında yeraltısuyu seviyesinde değişime neden olabilecek etkileri (pompaj, akarsudan sızma veya suni beslenme gibi) yansıtan parametreyi temsil etmektedir.

Eşitlikte yeralan k, doğal koşullar ile akiferden pompajla su çekilmesi durumundaki koşulları yansıtan bir katsayı olup, sayısal değerinin hesaplanmasında kullanılan eşitlik aşağıda (eşitlik 9) açıklanmıştır.

Jacob (1944) hareketli ortalamayı kullanarak yeraltısuyu seviyesinde yağışların etkili oldukları dönemleri belirlemeye çalışmıştır. Bredenkamp vd. (1995) ise Jacob (1944)'ten farklı olarak etkili dönemleri "kısa dönem hafıza" ve "uzun dönem hafıza" şeklinde tanımlamışlardır. Kısa dönem hafıza beslenme dönemini, uzun dönem hafıza ise seçilen zaman dilimine göre uzun yıllar/aylar ortalamasını temsil etmektedir. Bu yaklaşımla, OYES aşağıdaki şekilde tanımlanabilir; 
${ }_{n}^{m} O Y E S_{i}=\frac{1}{m} \sum_{j=i-(m-1)}^{j=i} P_{j}-k \cdot \frac{1}{n} \sum_{j=i-(n-1)}^{j=i} P_{j}+O Y E S_{i-1}$

Burada,

m: kısa dönem hafıza (beslenmenin gerçekleştiği dönem)

n: uzun dönem hafıza (analizde kullanılan yağış verilerinin oluşturduğu zaman serisi) olarak tanımlanmaktadır.

Kısa dönem hafıza, geriye doğru gidilirse beslenmenin en son hangi yağışlardan etkilenmiş olabileceği ile ilgilidir. Birimi, analizin yapıldığı zaman ölçeğine bağı olarak yıl, ay, gün olabilir. Örneğin, Mart ayında beslenmeden dolayı yeraltısuyu seviyesindeki değişime neden olan süzülme miktarı (beslenme miktarı) sadece Mart ayı yağışlarından oluşuyorsa bu hafıza "1 ay", Şubat ve Mart yağışlarından kaynaklıysa beslenmede etkili yağışın 2 ay geriye gideceği anlamı taşır ve bu da kısa dönem hafıza "2 ay", Ocak, Şubat ve Mart ayı yağışlarından etkileniyorsa, bu durumda kısa hafıza 3 ay olur ki bu da beslenmenin 3 aylık dönemlerde düşen yağışların etkisi altında olduğunu ifade eder. Kısa hafıza, diğer bir ifadeyle beslenme dönemi uzunluğu arttıkça, akiferin daha çok eklenik yağışların etkisi altında olduğu anlaşılır.

Öte yandan, akiferin yapısı, düşey hidrolik iletkenlik katsayısı ve yeraltısuyu seviyesinin derinliğine bağlı olarak yağışlardan süzülen suların doygun zona belirli bir gecikmeyle ulaşabildiği bilinmektedir. Yeraltısuyu seviyesinin yağışlara gecikmeli tepkisi, bu eşitliklerde "i" ile "j" indisleri değerleri ile ayarlanabilmektedir. Yağışların ortalamadan sapması ile yeraltısuyu seviye değişimleri arasındaki korelasyonun en yüksek değerinin elde edilebilmesi için hesaplamaların farklı gecikme süreleri (L) için yinelenmeleri gerekmektedir.

Doygun zonda hacimsel değişim ile ortalama yağıştan eklenik sapma arasındaki ilişkiyi veren eşitlik (5)'te OYES yerine eşitlik (7) yazılarak, eşitlik (8) elde edilir:

$V_{i}=c\left[\frac{1}{m} \sum_{j=i-(m-1)}^{j=i} P_{j}-k \cdot \frac{1}{n} \sum_{j=i-(n-1)}^{j=i} P_{j}+O Y E S_{i-1}\right]+$ sabit

Doğal kayıpların sabit olduğu varsayımı geçerli olmak üzere, bir örneği Şekil 1'de görüldüğü gibi, pompaj yapıldığında da yeraltısuyu seviyesindeki değişimler OYES ile uyumludur. Eşitlik (6)'da bir terim olarak bulunan $P_{m}$, pompaj etkisinin olduğu durumlarda k>1 olacağından $P_{\text {ort }}$ 'a eşit olmayacaktır (Bredenkamp vd, 1995). Pompaj durumunda k parametresi eşitlik (9) ile 
$k=1+\frac{Q}{A \cdot P_{\text {ort }}}$ olarak hesaplanabilir.

Burada, A: akifer alanı olarak tanımlanmıştır. Buna göre pompajın olmadığı durumda $\mathrm{Q}=0$ ve $\mathrm{k}=1$ olur.

Öte yandan, su denkliği eşitliği, S.dV=(I-O)+R-Q şeklinde yazılabilir.

Burada,

S: depolama katsayısı, dV: hacimsel değişim, R: beslenme, I: giren su hacmi, O: çıkan su hacmi ve $Q$ : pompajla alınan su hacmidir.

Su denkliği hacimsel değişim cinsinden yazılırsa,

$d V_{i}=\frac{R}{S}+\frac{(I-O-Q)}{S}$ ve beslenme ile yağış arasında doğrusal bir ilişki $(\mathrm{R}=\mathrm{C} . \mathrm{P})$ olduğu varsayımıyla eşitlik (10);

$d V_{i}=\frac{c}{S} P_{i}+b_{2}=b_{1} P_{i}+b_{2}$ yazılabilir

Burada, $b_{1}=\frac{c}{S}$ ve $b_{2}=\frac{1}{s}(I-O-Q)$ olarak tanımlanmıştır.

Dikkat edilirse, eşitlik (10) ile eşitlik (8) benzeşmektedir. Eşitlik (8)'deki $c$, $\frac{c}{s}$ ye karşılık gelir. Bu durumda, beslenme, R veya depolama katsayısı S, OYES ile V arasında kurulacak korelasyonla elde edilebilir. Diğer bir ifadeyle, eğer depolama katsayısı (S) bilinirse, beslenme, $\mathrm{R}$ hesaplanabilir, veya gözlenen yeraltısuyu seviyelerinin türetilmesi için S ve R optimize edilerek en uygun değerleri tahmin edilebilir.

\section{Örnek Uygulama}

Yukarıda kuramsal temelleri açıklanan "ortalama yağıştan eklenik sapma ile yeraltısuyu seviyelerinin türetilerek beslenme miktarının hesaplanması yöntemine" örnek uygulama için Antalya-Gazipaşa Ovası seçilmiştir. Adını Antalya iline bağlı Gazipaşa ilçesinden alan ova, kıyı alüvyonlarından oluşan bir düzlüğü kapsamaktadır (Şekil 2). Ova, topoğrafik olarak iki düzlükten meydana gelmiştir. Yer yer killi-siltli birimlerin görüldüğü ova alüvyonları genellikle kum ve çakıl gibi iri malzemelerden oluşmaktadır. 

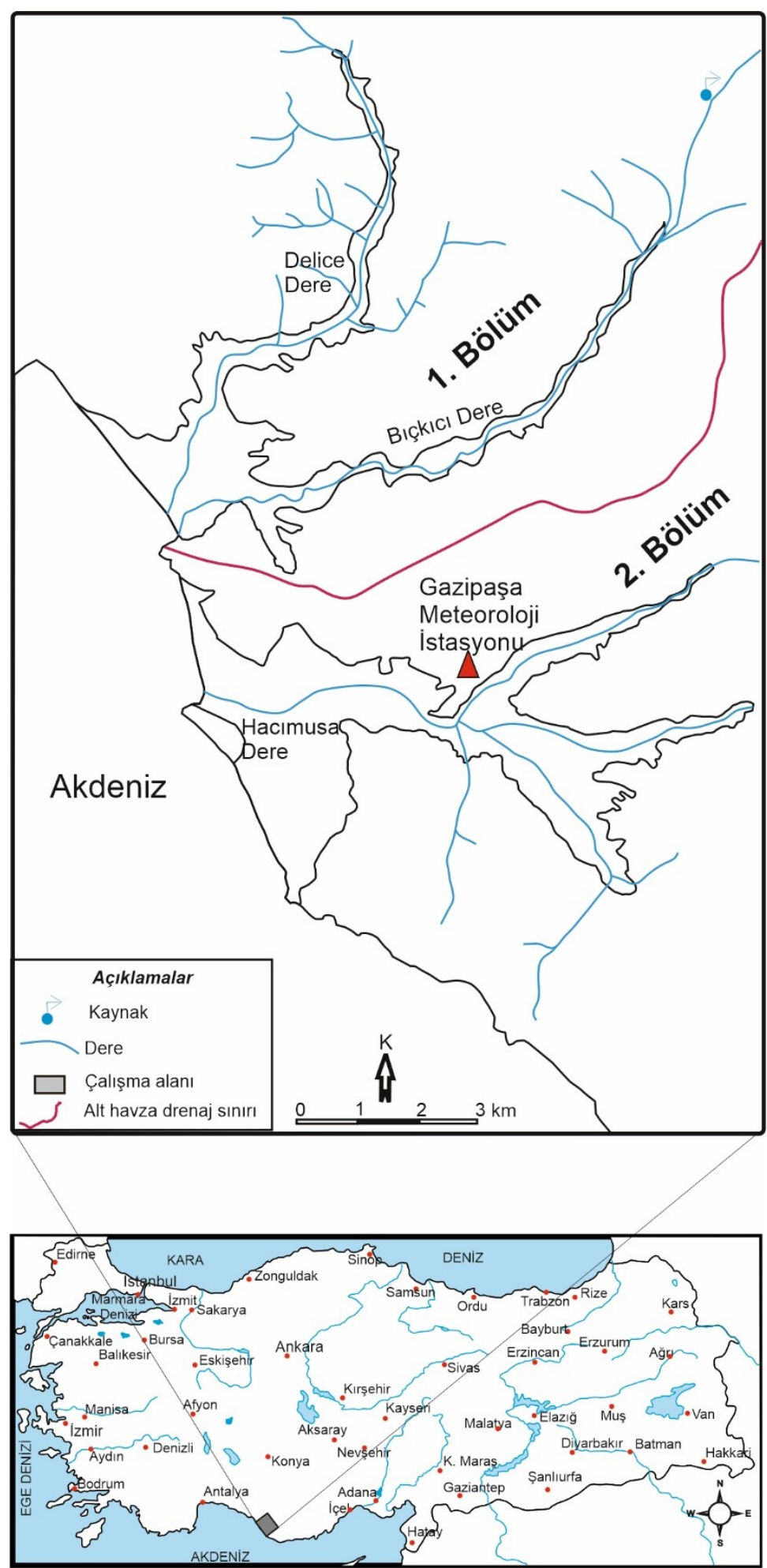

Şekil 2. Çalışma alanına ait yer bulduru haritası (DSi, 1973'ten değiştirilerek alınmıştır).

Figure 2. Location map of the study area (modified from DSI, 1973).

Gazipaşa Ovası akiferi hidrojeolojisi ile ilgili çeşitli çalışmalar literatürde bulunmaktadır (DSI, 1964; DSi, 1973; Keleş, 1996; Bozan, 2018). Bu çalışmada, Gazipaşa Ovası akiferinde Devlet Su İşleri Genel Müdülüğü'nün (DSi) 3926 ve 6512 numaralı gözlem kuyularının 1970-1971 yıllarına ait yeraltısuyu seviye verileri 
kullanılmıştır. Korkmaz (1978), 3926 ve 6512 numaralı kuyuların 1970-1971 su yıllarına ait yeraltısuyu seviyelerinden elde ettiği çekilme analizlerinden yararlanarak beslenme hesabı yapmıştır. Bu çalışmada, Korkmaz (1978) tarafından kullanılan kuyuların aynı döneme ait yeraltısuyu seviyeleri analiz edilmiş, bu şekilde iki farklı yaklaşım karşılaştırılabilmiştir. Korkmaz (1978), çalışmasında yağışları dikkate almamış, çekilme döneminde boşalım kotuna göre seviye değişimlerini analiz etmiştir.

Zamansal ölçek olarak aylık ölçümlerin seçildiği çalışmada, yeraltısuyu seviye gözlemlerinin yapıldığı döneme ait yağışlar, Gazipaşa Meteoroloji İstasyonu (GMi) kayıtlarından alınmıştır.

\section{Gazipaşa Ovası Akiferi ve Gözlem Kuyuları}

Gazipaşa Ovasını oluşturan düzlükler Kuvaterner yaşlı alüvyonlarla kaplıdır. Temelde Paleozoyik yaşlı şistler ve bunların üzerine gelen kireçtaşları yer alır. Ova akiferi, alanları sırasıyla $12 \mathrm{~km}^{2}$ ve $10 \mathrm{~km}^{2}$ olmak üzere iki bölümden oluşmakta, alüvyon akifer kalınlığı $10 \mathrm{~m}$ ile $60 \mathrm{~m}$ arasında değişmektedir. Ovada DSi tarafından araştırma, gözlem ve üretim amaçlı açılan kuyuların alüvyon ve alüvyonun altında bulunan konglomeralardan su aldıkları belirlenmiştir (DSi, 1973). Ovadaki iklimsel koşullar Gazipaşa Meteoroloji İstasyonunda ölçülen meteorolojik parametrelerle tanımlanabilmektedir. Bu istasyonda kaydedilen uzun yıllar (1970-2020) yağış ortalaması $843 \mathrm{~mm}$, ortalama hava sıcaklığı ise $18.7^{\circ} \mathrm{C}$ olarak hesaplanmıştır.

Drenaj alanı 719 km² olan ovanın Birinci Bölümünde Bıçkıcı ve Delice dereleri, İkinci Bölümünde ise Hacımusa dere havzanın yüzeysel akışlarını Akdenize ulaştırır (bkz. Şekil 2). Akarsuların 1972 yılında ölçülmüş debilerinin $0.012 \mathrm{~m}^{3} / \mathrm{s}$ ile $5.9 \mathrm{~m}^{3} / \mathrm{s}$ arasında değiştiği görülmektedir (Çizelge 1, DSi, 1973). Derelerin debileri yüksek değişkenlik göstermekte, bahar aylarında debileri $6 \mathrm{~m}^{3} / \mathrm{s}^{\prime}$ ye ulaşabilmektedir. Ovada önemli boşalıma sahip en önemli kaynak, Bıçkıcı derenin ovaya girişinden yaklaşık 5 km akışyukarıda boşalan kaynaktır. Bu kaynağın 1970-1971 yıllarında ölçülen debileri $0.378 \mathrm{~m}^{3} / \mathrm{s}$ ile $2.491 \mathrm{~m}^{3} / \mathrm{s}$ arasında değişmektedir (Çizelge 2, DSİ, 1973).

Gazipaşa ova akiferinin Birinci Bölüm olarak adlandırılan kısmında yayılım gösteren serbest akifer için hazırlanan yeraltısuyu bütçesine göre beslenme a) yağıştan doğrudan beslenme ve b) yüzeysel akıştan beslenme olarak gerçekleşmektedir. DSi (1973) tarafından yapılan hesaplamalar sonucunda beslenme ve boşalım yolları ve miktarlarını gösteren bütçe Çizelge 3'te verilmiştir. Bununla birlikte, ovanın bu kısmı için kurgulanan hidrojeolojik kavramsal modele göre akifere "dağönü beslenme" ve dere yataklarından sızma yoluyla da beslenmenin sözkonusu olduğu anlaşılmaktadır (Şekil 3). Şematik olarak verilen hidrojeolojik kavramsal modele göre dağönü beslenme ve dere yataklarından sızma ile yeraltısuyuna meydana gelen katkılar bu çalışma kapsamında aşağıdaki bölümlerde açıklanan yöntemle tahmin edilmiştir. 
Çizelge 1. Delice ve Bıçkıcı derelerine ait debi ölçüm değerleri (DSi, 1973).

Table 1. Measured flows of Delice and Bıçkıcı streams (DSi, 1973).

\begin{tabular}{lccc}
\hline Akarsu Adı & Debi Ölçü Yeri & Ölçme Tarihi & Debi $\left(\mathbf{m}^{\mathbf{3}} / \mathbf{s}\right)$ \\
\hline Delice Dere & Ova girişinde Çalıpınar mevkii & 29.03 .1972 & 0.243 \\
Delice Dere & Delice Karayolu Köprüsü & 29.03 .1972 & 0.432 \\
Delice Dere & Gölenizlik mevkii denize 150 m mesafede & 29.03 .1972 & 0.444 \\
Delice Dere & Ova girişinde Çalıpınar mevkii & 25.08 .1972 & 0.11 \\
Delice Dere & Gölenizlik mevkii denize 150 m mesafede & 25.08 .1972 & 0.027 \\
Bıçkıcı Dere & Ova girişinde Küçüklü mevkiinin doğusunda & 29.03 .1972 & 5.879 \\
Bıçkıcı Dere & Bıçkıcı Köprüsü & 29.03 .1972 & 5.116 \\
Bıçkıcı Dere & Ova girişinde Küçüklü mevkiinin doğusunda & 25.08 .1972 & 0.177 \\
Bıçkıcı Dere & Dere mansabında Inncirliyalısı mevkii & 25.08 .1972 & 0.012 \\
\hline
\end{tabular}

3926 numaralı kuyu Paşaçiftliği mevkiinde, 24.28 m kotunda ve 153 m derinliğinde araştırma kuyusu olarak açılmıştır. Gözlem amaçlı açılan 6512 numaralı kuyu ise Pazarcı Küçüklü mevkiinde, 36.18 m kotunda ve 35 m derinliğinde açılmıştır. Her iki kuyuda da kesilen litoloji kil bantlı konglomera olarak tanımlanmıştır (DSi, 1973). Kuyuların tamamının çakıllanarak filtrelendiği ve yeraltısuyu gözlemlerinin 1967 yılından itibaren başlamış olduğu anlaşılmaktadır.

Çizelge 2. Bıçkıcı deresi memba kaynağı debi değerleri (DSi,1973).

Table 2. Measured flows of Bıçkıcı upstream spring (DSI, 1973).

\begin{tabular}{cc}
\hline Ölçme Tarihi & Debi $\left(\mathbf{m}^{3} / \mathbf{s}\right)$ \\
\hline 25.06 .1970 & 0.751 \\
21.07 .1970 & 0.549 \\
17.08 .1970 & 0.481 \\
8.03 .1970 & 0.393 \\
12.10 .1970 & 0.378 \\
28.05 .1971 & 2.491 \\
8.07 .1971 & 0.673 \\
13.08 .1971 & 0.694 \\
24.09 .1971 & 0.448 \\
15.10 .1971 & 0.515 \\
10.11 .1971 & 0.616 \\
\hline
\end{tabular}

Analizlerde kullanılan yeraltısuyu seviyelerinin ölçüldüğü gözlem kuyularının konumu hesaplamalar açısından önemli bir etkiye sahiptir. Kuyuların derelere (beslenme sınır koşulu) veya pompaj yapılan kuyulara (kayıp sınır koşulu) göre konumları, 
yeraltısuyu seviyesi ile yağışlar arasındaki ilişkilerin analizlerinde dikkate alınmıştır. Bu çalışmada verileri kullanılan 3926 ve 6512 numaralı gözlem kuyuları Birinci Bölümde yer almaktadır. 3926 numaralı kuyu Bıçkıcı dere yatağına yaklaşık olarak 120 m, 6512 numaralı kuyu ise 500 m uzaklıktadır. Değerlendirmelerin yapıldığı 1970-1971 yıllarında işletme amaçı az sayıda kuyu bulunduğu, kuyulardan yıllık yaklaşık $1.0^{*} 10^{6} \mathrm{~m}^{3}$ su çekildiği raporlanmıştır (DSI, 1973). Yeraltısuyu çekiminin yapıldığı kuyu alanlarının 3926 ve 6512 numaralı gözlem kuyularına uzaklıkları sırasıyla yaklaşık $1 \mathrm{~km}$ ve $2 \mathrm{~km}$ olarak belirlenmiştir (Şekil 4).

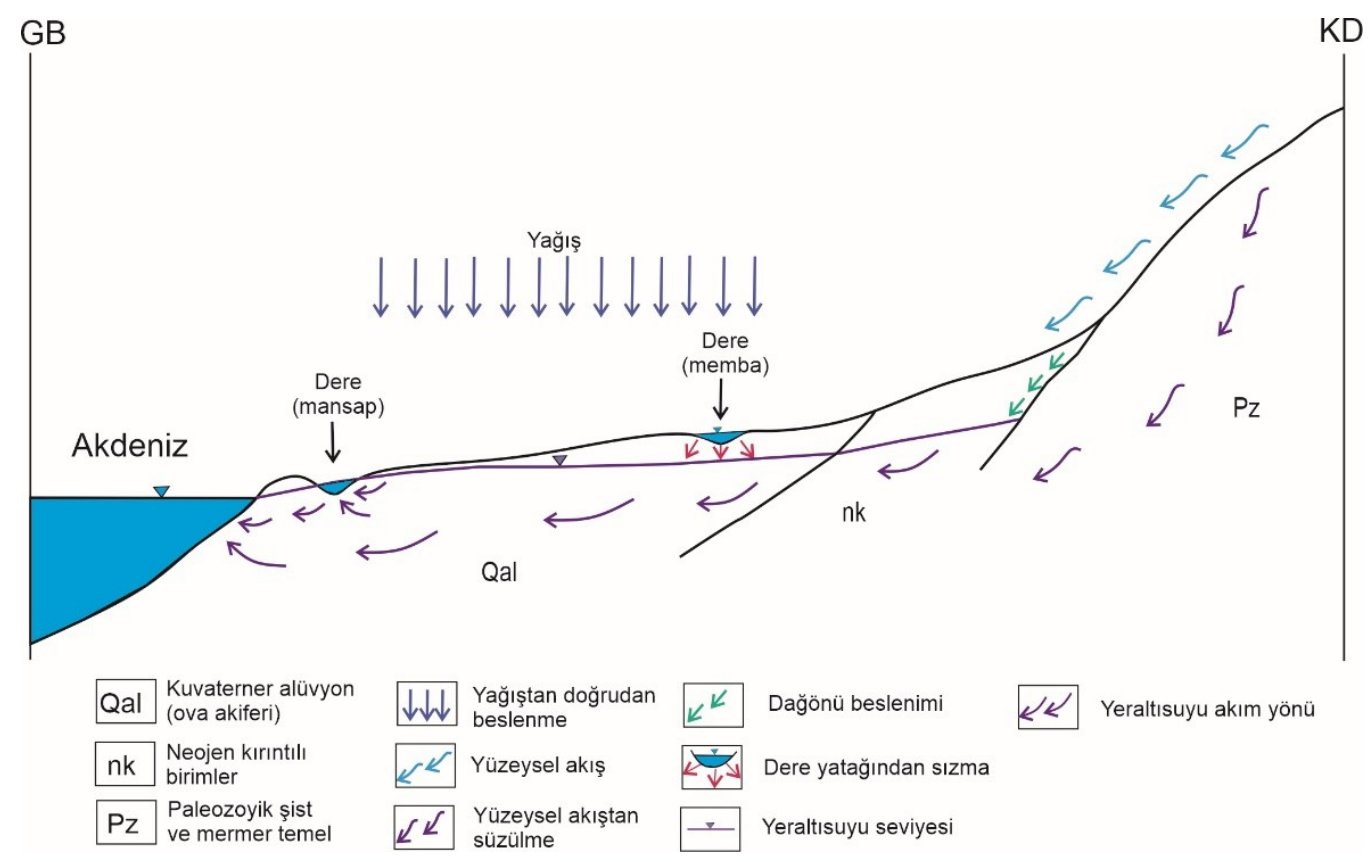

Şekil 3. Gazipaşa ova akiferi birinci kısmına ait şematik hidrojeolojik kavramsal model.

Figure 3. Schematic hydrogeological conceptual model for first part of Gazipaşa plain aquifer.

\section{Yeraltısuyu Gözlemleri ve Yağış Kayıtları}

Bu çalışmada kullanılan 3926 ve 6512 numaralı kuyuların 1970 ve 1971 su yıllarına ait yeraltısuyu seviyeleri hidrolik yük olarak Çizelge 4 'te verilmiştir. Çalışmada dikkate alınan dönem içinde 3926 nolu kuyuda yeraltısuyu seviyesinin kot olarak en düşük değeri Kasım 1971 ayında (8.76 m), en yüksek değeri (12.98 m) ise Nisan 1970 ayında kaydedilmiş, yeraltısuyu seviyesinin bu dönem içinde $4.22 \mathrm{~m}$ değiştiği 
gözlenmiştir. Benzer şekilde, 6512 nolu kuyuda ise yeraltısuyu seviyeleri en düşük $(10.78 \mathrm{~m})$ ve en yüksek $(16.24 \mathrm{~m})$ olarak sırasıyla Kasım 1971 ve Mart 1970'te kaydedilmiş, yeraltısuyu seviyesi değişiminin 5.46 m olarak gerçekleştiği gözlenmiş̧ir.

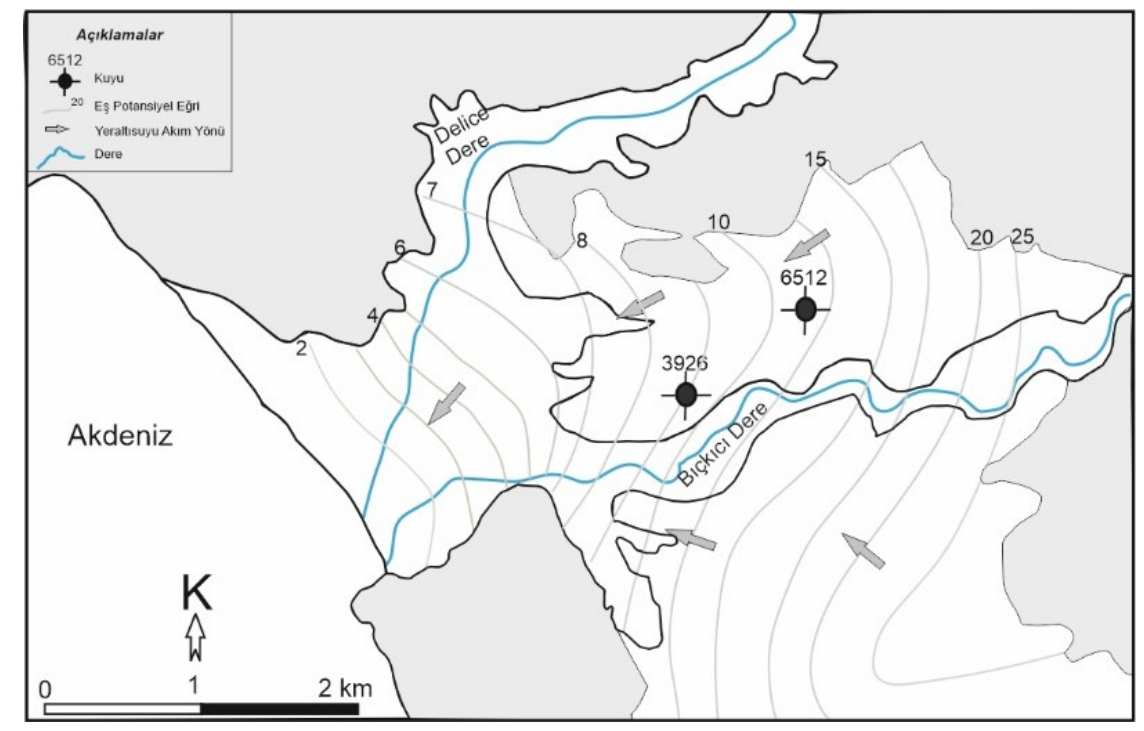

Şekil 4. Sadeleştirilmiş hidrojeoloji haritası.

Figure 4. Simplified hydrogeological map of the study area.

Çizelge 3. Gazipaşa ova akiferi birinci bölümü yeraltısuyu bütçesi özeti (DSi, 1973)

Table 3. Summary of groundwater budget of first part of Gazipaşa plain aquifer (DSi, 1973)

\begin{tabular}{ll|ll}
\hline \multicolumn{1}{c|}{ BESLENiM } & $\boldsymbol{m}^{3} / \boldsymbol{y ı l}$ & \multicolumn{1}{c}{ BOŞALIM } & $\boldsymbol{m}^{3} / \mathbf{y l}$ \\
\hline Yağıştan Süzülme: & $2 \times 10^{6}$ & Sı̆̆ Kuyularla Çekim: & $1 \times 10^{6}$ \\
Yüzeysel Akıştan Süzülme: & $7 \times 10^{6}$ & Buharlaşma-Terleme: & $1.5 \times 10^{6}$ \\
& & Akdeniz'e Boşalım: & $6.5 \times 10^{6}$ \\
\hline TOPLAM & $9 \times 10^{6}$ & & $9 \times 10^{6}$ \\
\hline
\end{tabular}


Çizelge 4. Bu çalışmada kullanılan yeraltısuyu seviyeleri ile yağışlara ait veriler.

Table 4. Groundwater levels and rainfall data used in this study.

\begin{tabular}{|c|c|c|c|c|c|}
\hline \multirow{3}{*}{ Tarih } & \multirow{2}{*}{\multicolumn{2}{|c|}{ Yeraltısuyu Kotu (m) }} & \multirow{3}{*}{$\begin{array}{l}\text { Aylık } \\
\text { Yağış } \\
\text { (mm) }\end{array}$} & \multicolumn{2}{|c|}{ Yeraltısuyu Seviyesi } \\
\hline & & & & \multicolumn{2}{|c|}{ Ortalamadan Sapma (m) } \\
\hline & 3926 & 6512 & & 3926 & 6512 \\
\hline Ekim 69 & 9.28 & 11.64 & 45.2 & -1.302 & -1.623 \\
\hline Kasım 69 & 10.27 & 12.88 & 99.7 & -0.312 & -0.383 \\
\hline Aralık 69 & 10.35 & 12.89 & 97 & -0.232 & -0.373 \\
\hline Ocak 70 & 12.07 & 15.4 & 45.4 & 1.488 & 2.137 \\
\hline Şubat 70 & 11.34 & 15.18 & 181 & 0.758 & 1.917 \\
\hline Mart 70 & 12.46 & 16.24 & 56.3 & 1.878 & 2.977 \\
\hline Nisan 70 & 12.98 & 16.07 & 74.4 & 2.398 & 2.807 \\
\hline Mayıs 70 & 11.88 & 15.39 & 9.5 & 1.298 & 2.127 \\
\hline Haziran 70 & 11.86 & 15.22 & 11.4 & 1.278 & 1.957 \\
\hline Temmuz 70 & 10.88 & 14.33 & & 0.298 & 1.067 \\
\hline Ağustos 70 & 10.2 & 13.3 & 2.4 & -0.382 & 0.037 \\
\hline Eylül 70 & 10.13 & 11.89 & & -0.452 & -1.373 \\
\hline Ekim 70 & 9.14 & 11.74 & 0 & -1.442 & -1.523 \\
\hline Kasım 70 & 9.75 & 11.44 & 136.8 & -0.832 & -1.823 \\
\hline Aralık 70 & 10.18 & 11.96 & 48.7 & -0.402 & -1.303 \\
\hline Ocak 71 & 10.48 & 12.84 & 82.6 & -0.102 & -0.423 \\
\hline Şubat 71 & 9.68 & 11.23 & 137.3 & -0.902 & -2.033 \\
\hline Mart 71 & 10.06 & 11.77 & 57.6 & -0.522 & -1.493 \\
\hline Nisan 71 & 11.48 & 14.76 & 67.6 & 0.898 & 1.497 \\
\hline Mayıs 71 & 11.33 & 14.69 & 73.1 & 0.748 & 1.427 \\
\hline Haziran 71 & 10.88 & 14.19 & 3.6 & 0.298 & 0.927 \\
\hline Temmuz 71 & 10.58 & 13.39 & 1.2 & -0.002 & 0.127 \\
\hline Ağustos 71 & 10.1 & 12.64 & & -0.482 & -0.623 \\
\hline Eylül 71 & 9.72 & 11.78 & 15.2 & -0.862 & -1.483 \\
\hline Ekim 71 & 9.28 & 11.19 & 141.9 & -1.302 & -2.073 \\
\hline Kasım 71 & 8.76 & 10.78 & 28.1 & -1.822 & -2.483 \\
\hline
\end{tabular}

Bu çalışmada yapılan analizlerde yararlanılan yağış verileri, ova alanı içinde $21 \mathrm{~m}$ kotunda bulunan Gazipaşa Meteoroloji İstasyonu kayıtlarından elde edilmiştir. Analizlerin gerçekleştirildiği dönemde kaydedilen toplam yağışlar Çizelge 4'te verilmiştir. Şekil 5'te kuyularda kaydedilen yeraltısuyu seviyeleri hidrolik yük cinsinden yağışlarla birlikte grafik üzerinde gösterilmiştir. Şekilde görüldüğü gibi yeraltısuyu seviyeleri ile yağışlar arasında genel bir uyumdan söz edebilmek kolay 
değildir. Bununla birlikte, yüksek yağışların yeraltısuyu seviyelerine etkilerinin 2 aylık bir gecikmeden sonra meydana geldiği çıkarsanabilir. Yağışla, 2 ay sonraki yeraltısuyu seviyeleri arasındaki ilişkinin zayıflığına işaret eden dağınıklık Şekil 6'da verilen grafikten de görülebilmektedir. Regresyon eşitlikleri incelendiğinde, 3926 nolu kuyuda ölçülen seviyelerin aylık yağışlarla daha yüksek bir korelasyon sunduğu anlaşılmaktadır.

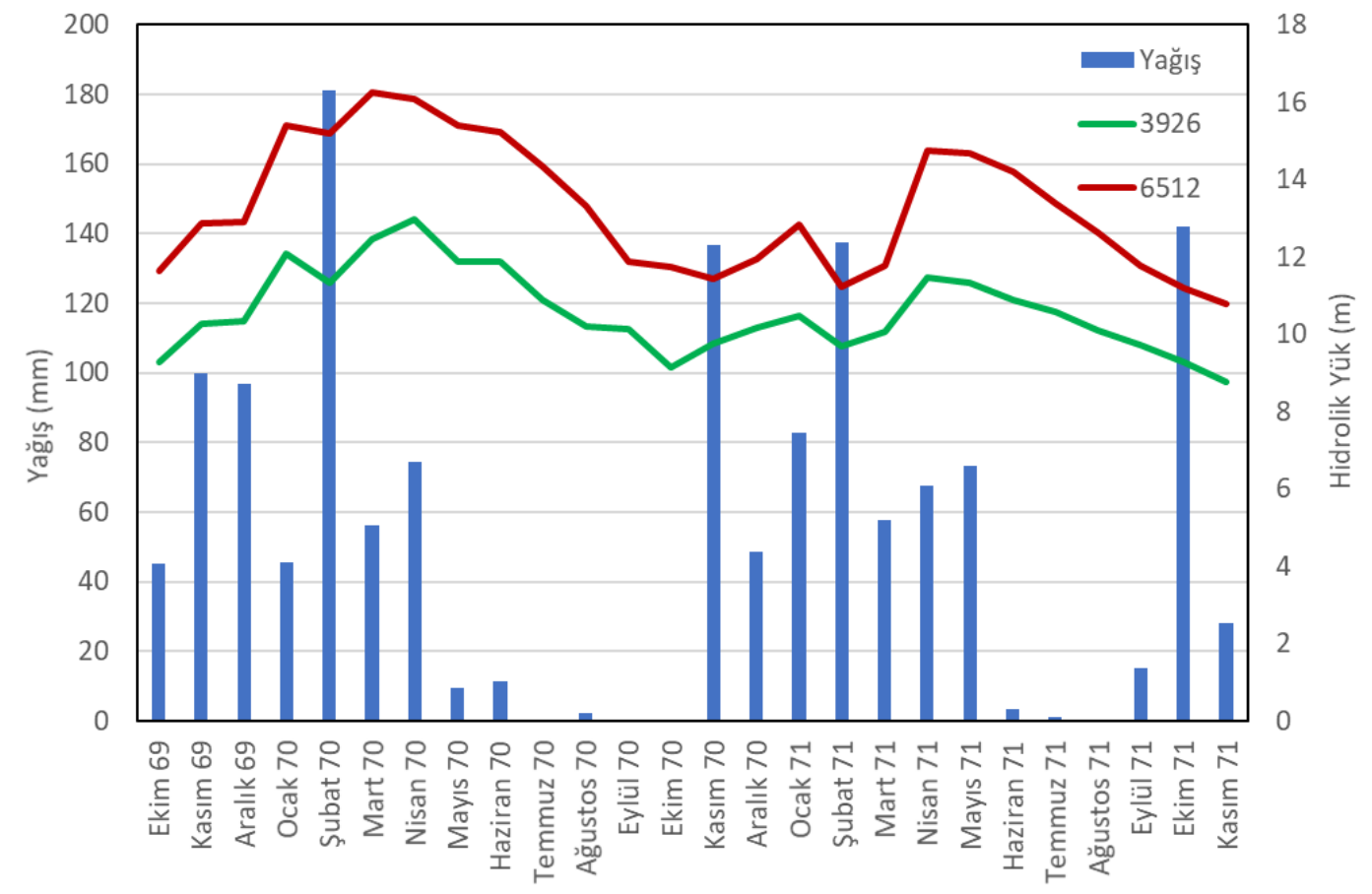

Şekil 5. 1970 ve 1971 su yıllarına ait 3926 ve 6512 nolu kuyuların yeraltısuyu seviyeleri ile Gazipaşa Meteoroloji İstasyonu yağışları.

Figure 5. Groundwater levels measured in wells 3926 and 6512 and rainfall data for water years 1970 and 1971 . 


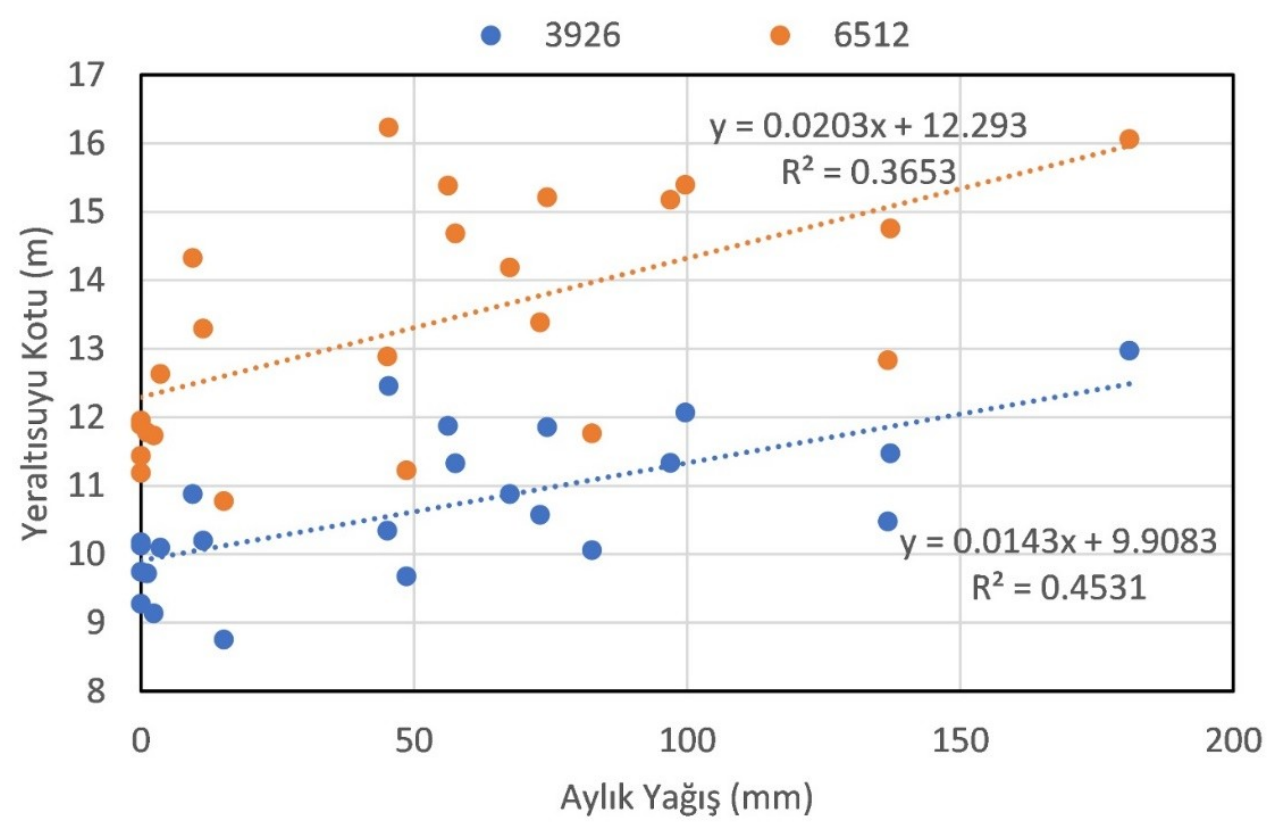

Şekil 6. Aylık toplam yağışlarla, 2 ay gecikmeyle 3926 ve 6512 nolu kuyulara ait yeraltısuyu seviyeleri arasındaki ilişki.

Figure 6. Relationship between groundwater levels measured in wells 3926 and 6512 and monthly rainfall with time lag of 2 months.

\section{Yeraltısuyu Seviyelerinde Ortalamadan Sapma}

Yeraltısuyu seviyelerindeki dalgalanmaların daha açık bir şekilde görülebilmesi amacıyla seviyelerin ortalama seviyeden sapma miktarları hesaplanmıştır. Çizelge 4'te görülen sapmaların 3926 nolu kuyu için $-1.822 \mathrm{~m}$ ile $+2.398 \mathrm{~m}$ arasında; 6512 nolu kuyu için -2.483 ile $+2.977 \mathrm{~m}$ arasında olduğu görülmektedir. Yeraltısuyu seviyelerinin hesaplanan ortalamadan sapmaları yağışlarla deneştirilmiş, yağışlarla olan ilişkinin daha belirgin bir hale gelmesi sağlanmıştır (Şekil 7). Grafikten yağışların yeraltısuyu seviyelerine yansımasının 2 ay gecikmeyle gerçekleştiği daha belirgin bir şekilde gözlenebilmektedir. Bu nedenle, örneğin Ekim 1971 yılında 141.9 mm düzeyinde gerçekleşen toplam yağışın henüz yeraltısuyu seviyelerine herhangi bir etkisi olmadığı görülmektedir. Öte yandan benzer yağışların yeraltısuyu seviyelerine aynı düzeyde etki etmedikleri beslenme mekanizmasının doğrusal olmadığının bir göstergesi olarak değerlendirilmelidir. 


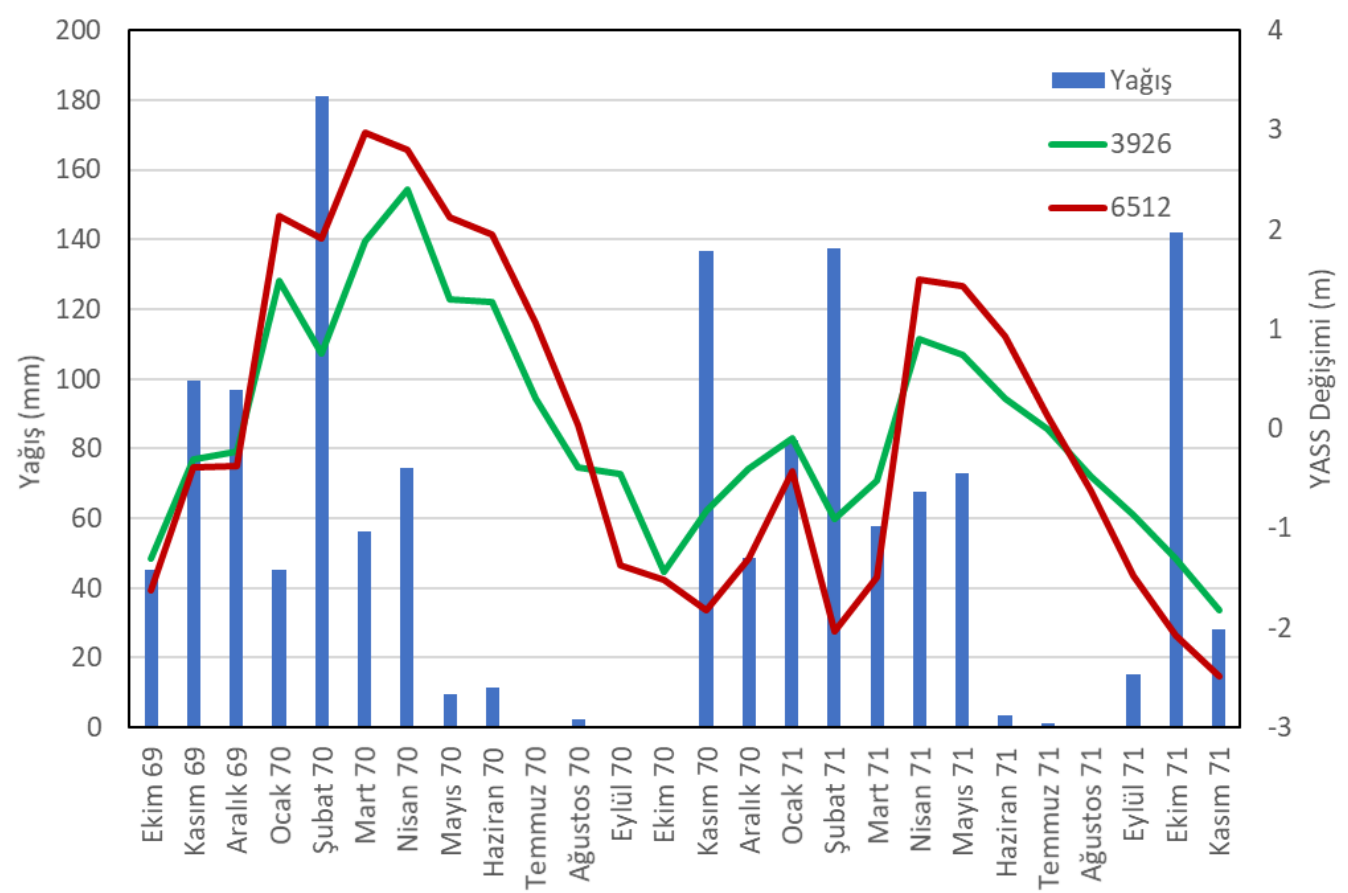

Şekil 7. Aylık toplam yağışlarla 3926 ve 6512 nolu kuyulara ait yeraltısuyu seviyelerinin ortalamadan sapmaları arasındaki ilişki.

Figure 7. Relationship between departure of groundwater levels from the average in wells 3926 and 6512 and the monthly rainfall.

\section{Yağışlardan İtibaren Yeraltısuyu Seviyelerinin Türetilmesi}

Yeraltısuyu seviyelerindeki değişimlerin doğrudan yağışla ilişkilendirilmesi, beslenme miktarının hesaplanmasında temel varsayımların başında gelmektedir. Yeraltısuyu sisteminin açık bir sistem olmadığı, akarsu yataklarından sızma yoluyla akifere bir katkının söz konusu olmadığı, benzer şekilde yeraltısuyu seviyesinin düşmesine neden olabilecek pompajla boşalım gibi bir dış etkinin bulunmadığı kabul edilmektedir. Bu varsayımlarla 7 ve 10 nolu eşitliklerden yararlanılarak yeraltısuyu seviyesi 3926 ve 6512 nolu kuyular için yeniden türetilmiştir. Dış etkinin bulunmadığı varsayımıyla gerçekleştirilen analizlerde eşitlik (7)'deki ilgili parametre bu varsayıma uygun olarak $k=1$, ve eşitlik (10)'da boşalım $(O)$ ve pompaj $(Q)$ etkisinin olmadığını belirtmek üzere $O=Q=0$ alınmıştır. Her iki kuyuda gözlenen yeraltısuyu seviyelerinin yağışlardan yaklaşık 2 aylık bir gecikmeyle etkilendikleri gözönünde bulundurularak analizlerde gecikme süresi 2 ay olarak alınmıştır. Öte yandan, eşitlik (7)'de "uzun dönem hafıza" serinin tamamını kapsayacak şekilde 26 ay olarak alınmıştır. Beslenmeye katkıda bulunan süreyi temsil eden "kısa dönem hafıza" ve depolama katsayısı/özgül verim ise "gözlenen seviye-hesaplanan seviye" arasında en yüksek ilişkiyi verecek şekilde optimize edilerek sırasıyla 3 ay ve 0.1 olarak belirlenmiştir. Her 
iki kuyu için "gözlenen seviye-hesaplanan seviye" arasındaki en yüksek korelasyon 2 aylık gecikme süresi, 3 aylık kısa dönem hafıza ve 0.1 özgül verim değeriyle elde edilmiştir. Hesaplamalarda kullanılan parametreler ve değerleri Çizelge 5 'te, her iki kuyu için elde edilen sonuçlar ise Çizelge 6'da verilmiştir. Aylık yeraltısuyu seviyelerinin $\left(\right.$ YASS $_{i}$ ) iki su yılı ortalamasına (YASS ort) göre sapması olarak tanımlanan dalgalanma

$d Y A S S=Y A S S_{i}-Y A S S_{\text {ort }}$

eşitliği ile hesaplanmıştır.

3926 nolu kuyu için OYES yöntemiyle hesaplanan yeraltısuyu seviyesindeki dalgalanma ile gözlenen seviye dalgalanmaları yağış verileriyle birlikte Şekil 8'de gösterilmiştir. Görüldüğü gibi ortalamadan eklenik sapma yöntemiyle türetilen yeraltısuyu seviyesindeki dalgalanma ile gözlenen seviye dalgalanmaları arasında genel bir uyum elde edilmesine karşın, özellikle ekstrem (düşük-yüksek) değerlerde fark daha önemli hale gelmektedir.

Çizelge 5. Hesaplamalarda kullanılan parametre, değişken ve değerleri.

Table 5. Parameters, variables and their values used in calculations.

\begin{tabular}{lcc}
\hline Parametre/Değişken & Simge & Değer \\
\hline Seri uzunluğu/uzun hafıza (ay) & $\mathrm{n}$ & 26 \\
Beslenme dönemi/kısa hafıza (ay) & $\mathrm{m}$ & 3 \\
Gecikme süresi (ay) & $\mathrm{L}$ & 2 \\
Uzun dönem ortalama aylık yağış (mm/ay) & $\mathrm{P}_{\text {ort }}$ & 61.57 \\
Etkin gözeneklilik/Özgül verim & Sy & 0.1 \\
Havza/Beslenme Alanı (km ${ }^{2}$ ) & $\mathrm{A}$ & 12 \\
Doğal koşullar için pompaj debisi (m³/ay) & $\mathrm{Q}$ & 0 \\
Doğal koşullar için pompaj etki katsayısı & $\mathrm{k}$ & 1 \\
Pompaj debisi (m³/ay) & $-\mathrm{Q}$ & Her aydaki değeri \\
Dereden sızma debisi (m $\left.{ }^{3} / a y\right)$ & $\mathrm{Q}$ & için bkz. Çizelge 6 \\
\hline
\end{tabular}




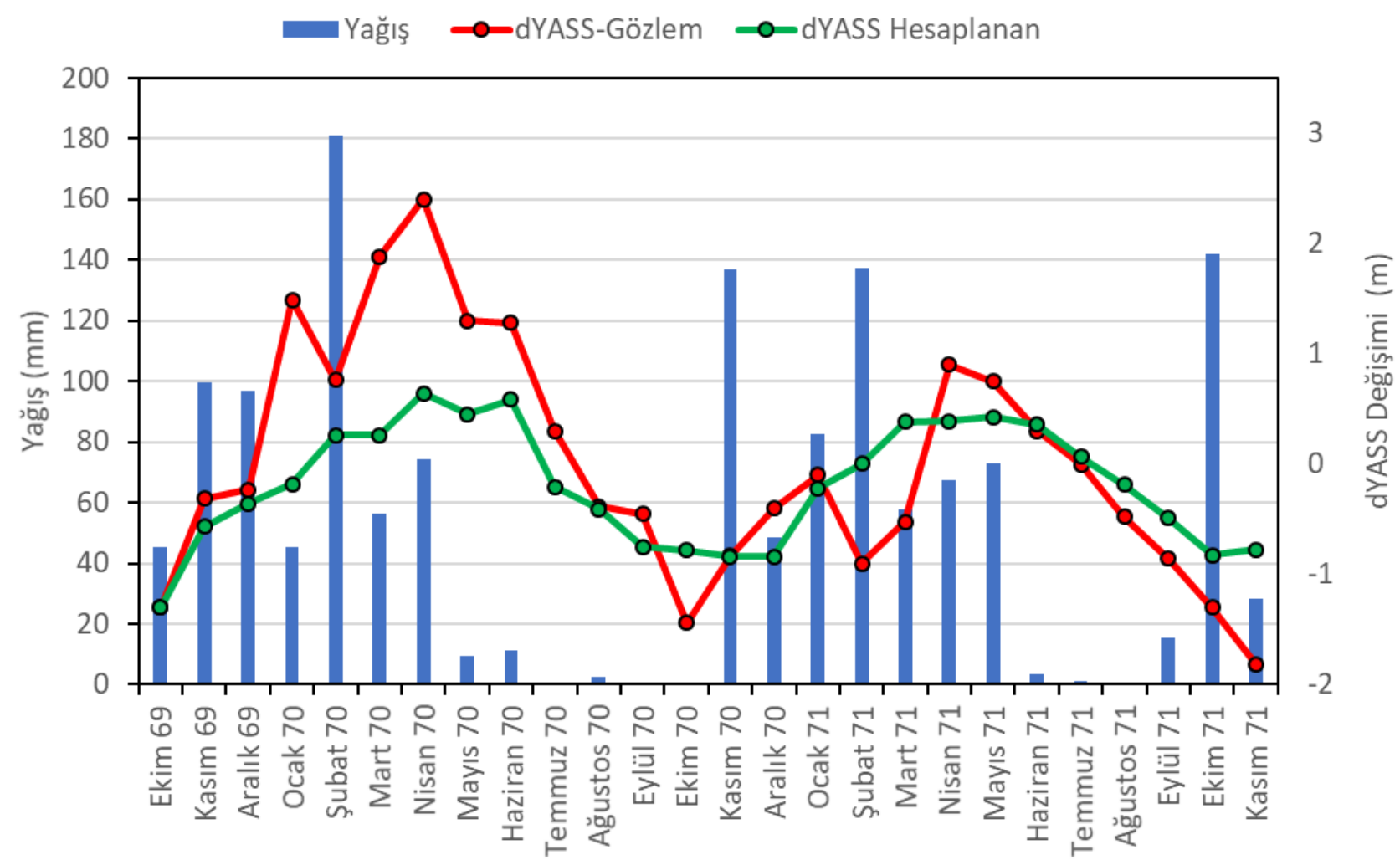

Şekil 8. 3926 nolu kuyu için dış etkilere kapalı sistem varsayımıyla OYES yöntemiyle türetilen yeraltısuyu seviyesi ile gözlenen seviye.

Figure 8. Observed and calculated groundwater levels for well no applying CRD for 3926 assuming a closed system.

3926 nolu kuyu için hesaplanan değerler ile gözlenen değerler arasındaki ilişki düzeyini de ifade etmekte kullanılan determinasyon katsayısı $\left(R^{2}\right)$ Şekil 9'da verilen regresyon grafiğinde 0.61 olarak belirlenmiştir. Bu değer, r=0.78'lik bir Pearson korelasyon katsayısına karşılık gelmektedir. Bu değer, istatistiksel olarak, hesaplanan ile gözlenen değerler arasında önemli düzeyde bir korelasyonun varlığına işaret etmektedir. Şekil 9'da negatif sapmalarda noktaların daha dağınık, dolayısıyla korelasyonun daha düşük olduğu görülmektedir. Bu durum, yağışlı dönemlerdeki uyumun, kurak dönemlere oranla daha yüksek olduğu anlamı taşımaktadır. 


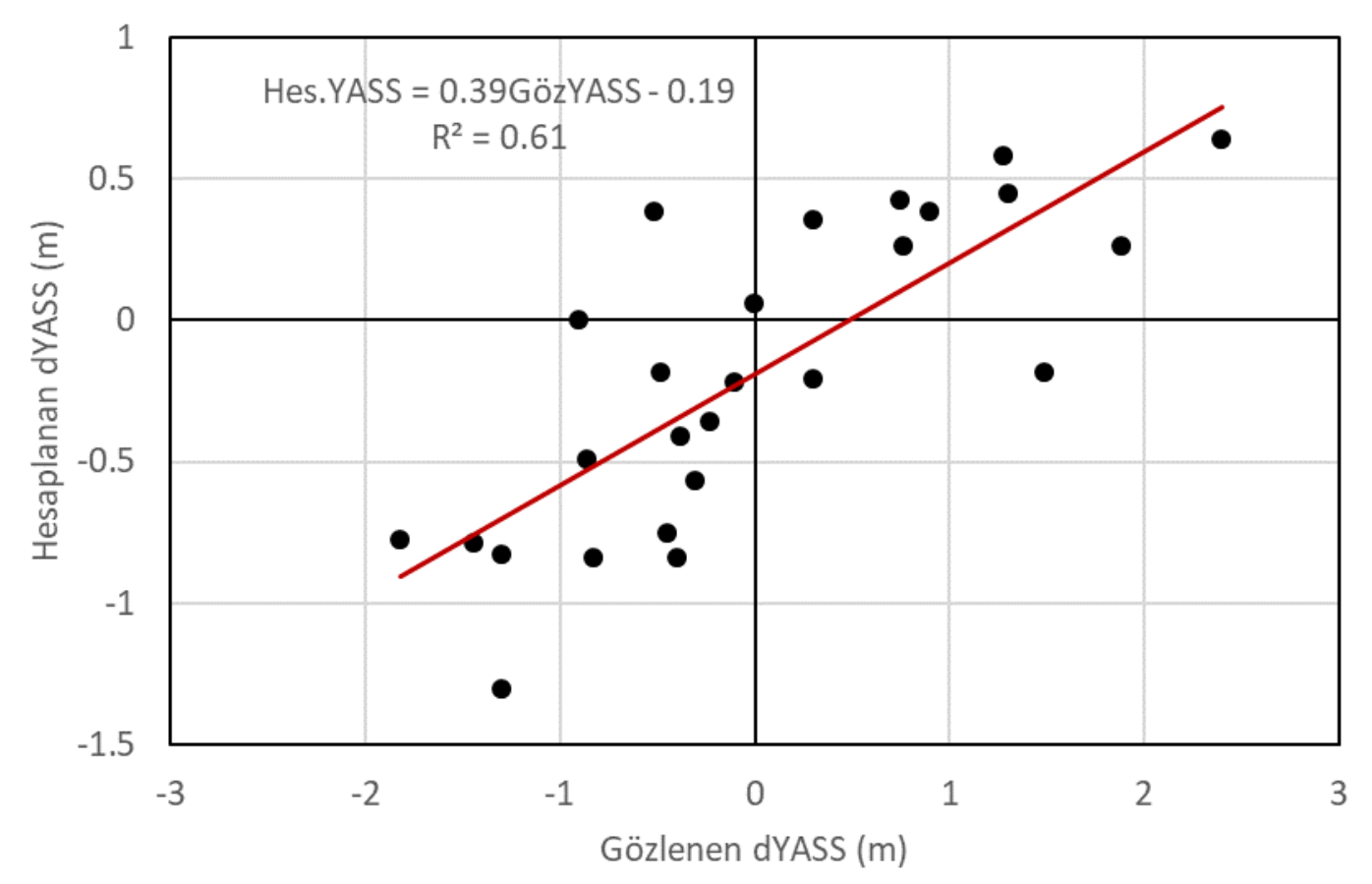

Şekil 9. 3926 nolu kuyu için dış etkilere kapalı sistem varsayımıyla OYES yöntemiyle türetilen yeraltısuyu seviyesi ile gözlenen seviye arasındaki ilişki.

Figure 9. Regression beween the observed and calculated groundwater levels for well no applying CRD for 3926 assuming a closed system.

Benzer şekilde, OYES yöntemiyle türetilen yeraltısuyu seviyesindeki dalgalanmalar ile 6512 nolu kuyuda gözlenen yeraltısuyu seviye değişimleri Şekil 10'da gösterilmiştir. Bu kuyu için yapılan analizlerde, gözlenen ile hesaplanan dalgalanmalar 3926 kuyusuna göre daha düşük bir uyum göstermiştir. Şekil 10'da görüldüğü gibi, uyumun düşük olduğu noktalar, benzer şekilde yüksek yağış dönemleri ile kurak dönemleri temsil eden ekstrem değerlere karşılık gelmektedir.

Gözlenen sapmalarla hesaplanan sapmalar arasındaki uyumun sayısal değerinin belirlenmesi için gerçekleştirilen regresyon analizi, regresyon eşitliği ve determinasyon katsayısı ile birlikte Şekil 11'de grafiksel olarak gösterilmiştir. 6512 nolu kuyuda determinasyon katsayısı 0.57 olarak belirlenmiştir. Pearson korelasyon katsayısı r=0.75 olup istatistiksel olarak yüksek bir korelasyondan söz edilebilir. 
Çizelge 6. Çalışmada kullanılan kuyularda, dış etkilere kapalı sistem varsayımıyla, gözlenen ve hesaplanan yeraltısuyu seviyelerinin ortalamadan sapması.

Table 6. Observed and calculated deviations of groundwater levels from the average for well no applying CRD for the wells used in this study assuming a closed system.

\begin{tabular}{lccccc}
\hline & & \multicolumn{2}{c}{3926 nolu Kuyu } & \multicolumn{2}{c}{ 6512 nolu Kuyu } \\
\hline \multicolumn{1}{c}{ Aylar } & $\begin{array}{c}\text { Yağış } \\
\text { (mm) }\end{array}$ & $\begin{array}{c}\text { dYASs } \\
\text { Gözlenen }\end{array}$ & $\begin{array}{c}\text { dYASS } \\
\text { Hesaplanan }\end{array}$ & $\begin{array}{c}\text { dYASS } \\
\text { Gözlenen }\end{array}$ & $\begin{array}{c}\text { dYASS } \\
\text { Hesaplanan }\end{array}$ \\
\hline Ekim 69 & 45.2 & -1.302 & -1.302 & -1.623 & -1.623 \\
Kasım 69 & 99.7 & -0.312 & -0.566 & -0.383 & -0.878 \\
Aralık 69 & 97.0 & -0.232 & -0.358 & -0.373 & -0.556 \\
Ocak 70 & 45.4 & 1.488 & -0.183 & 2.137 & -0.284 \\
Şubat 70 & 181.0 & 0.758 & 0.263 & 1.917 & 0.408 \\
Mart 70 & 56.3 & 1.878 & 0.264 & 2.977 & 0.409 \\
Nisan 70 & 74.4 & 2.398 & 0.638 & 2.807 & 0.989 \\
Mayıs 70 & 9.5 & 1.298 & 0.451 & 2.127 & 0.699 \\
Haziran 70 & 11.4 & 1.278 & 0.584 & 1.957 & 0.906 \\
Temmuz 70 & & 0.298 & -0.205 & 1.067 & -0.317 \\
Ağustos 70 & 2.4 & -0.382 & -0.411 & 0.037 & -0.638 \\
Eylül 70 & & -0.452 & -0.753 & -1.373 & -1.168 \\
Ekim 70 & & -1.442 & -0.786 & -1.523 & -1.219 \\
Kasım 70 & 136.8 & -0.832 & -0.838 & -1.823 & -1.300 \\
Aralık 70 & 48.7 & -0.402 & -0.838 & -1.303 & -1.300 \\
Ocak 71 & 82.6 & -0.102 & -0.220 & -0.423 & -0.342 \\
Şubat 71 & 137.3 & -0.902 & 0.004 & -2.033 & 0.006 \\
Mart 71 & 57.6 & -0.522 & 0.383 & -1.493 & 0.595 \\
Nisan 71 & 67.6 & 0.898 & 0.386 & 1.497 & 0.598 \\
Mayıs 71 & 73.1 & 0.748 & 0.427 & 1.427 & 0.662 \\
Haziran 71 & 3.6 & 0.298 & 0.358 & 0.927 & 0.555 \\
Temmuz 71 & 1.2 & -0.002 & 0.063 & 0.127 & 0.097 \\
Ağustos 71 & & -0.482 & -0.186 & -0.623 & -0.288 \\
Eylül 71 & 15.2 & -0.862 & -0.491 & -1.483 & -0.762 \\
Ekim 71 & 141.9 & -1.302 & -0.827 & -2.073 & -1.283 \\
Kasım 71 & 28.1 & -1.822 & -0.774 & -1.200 & -1.657 \\
\hline & & & & &
\end{tabular}

Şekil 11'de verilen grafikteki noktaların dağılımı incelendiğinde, dağınıkığın gözlenen değerlerin negatif olduğu kesimde daha yüksek olduğu görülmektedir. Bu durum, 3926 nolu kuyuda olduğu gibi, kurak dönemlerde korelasyonun düştüğü anlamına gelmektedir. Şekil 9 ve Şekil 11 'de verilen her iki kuyuda da yağışlı dönemleri temsil eden pozitif sapmaları gösteren kesimlerde de daha düşük sayıda da olsa bazı noktalarda dağınıklık olduğu dikkati çekmektedir. Grafiklerin pozitif kesimlerinde dağınıklığı arttıran noktaların aylık yağışların çok yüksek olduğu, yüzeysel akışın taşkın dönemlerine karşılık geldiği anlaşılmaktadır. 


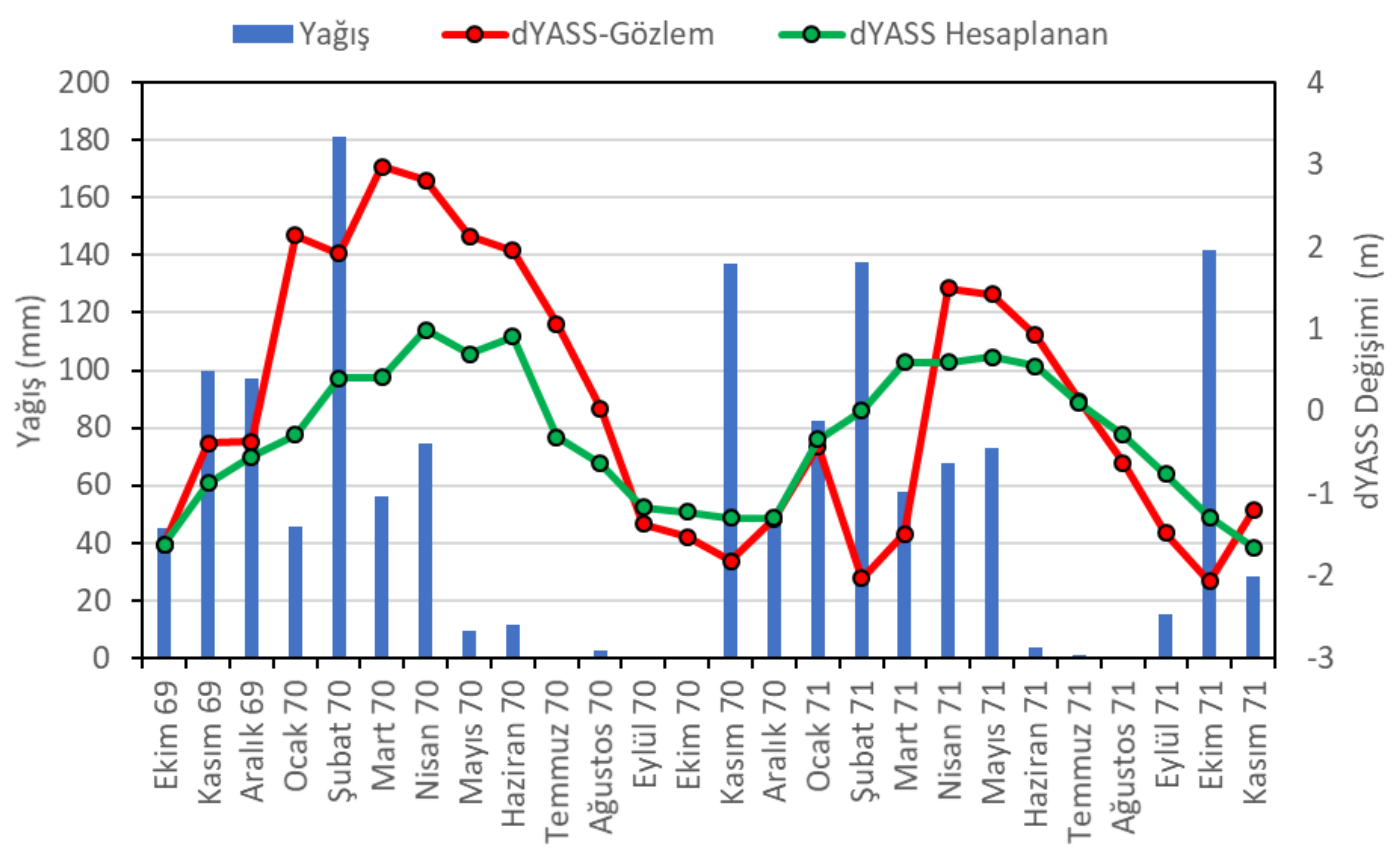

Şekil 10. 6512 nolu kuyu için dış etkilere kapalı sistem varsayımıyla OYES yöntemiyle türetilen yeraltısuyu seviyesi ile gözlenen seviye.

Figure 10. Observed and calculated groundwater levels for well no applying CRD for 6512 assuming a closed system.

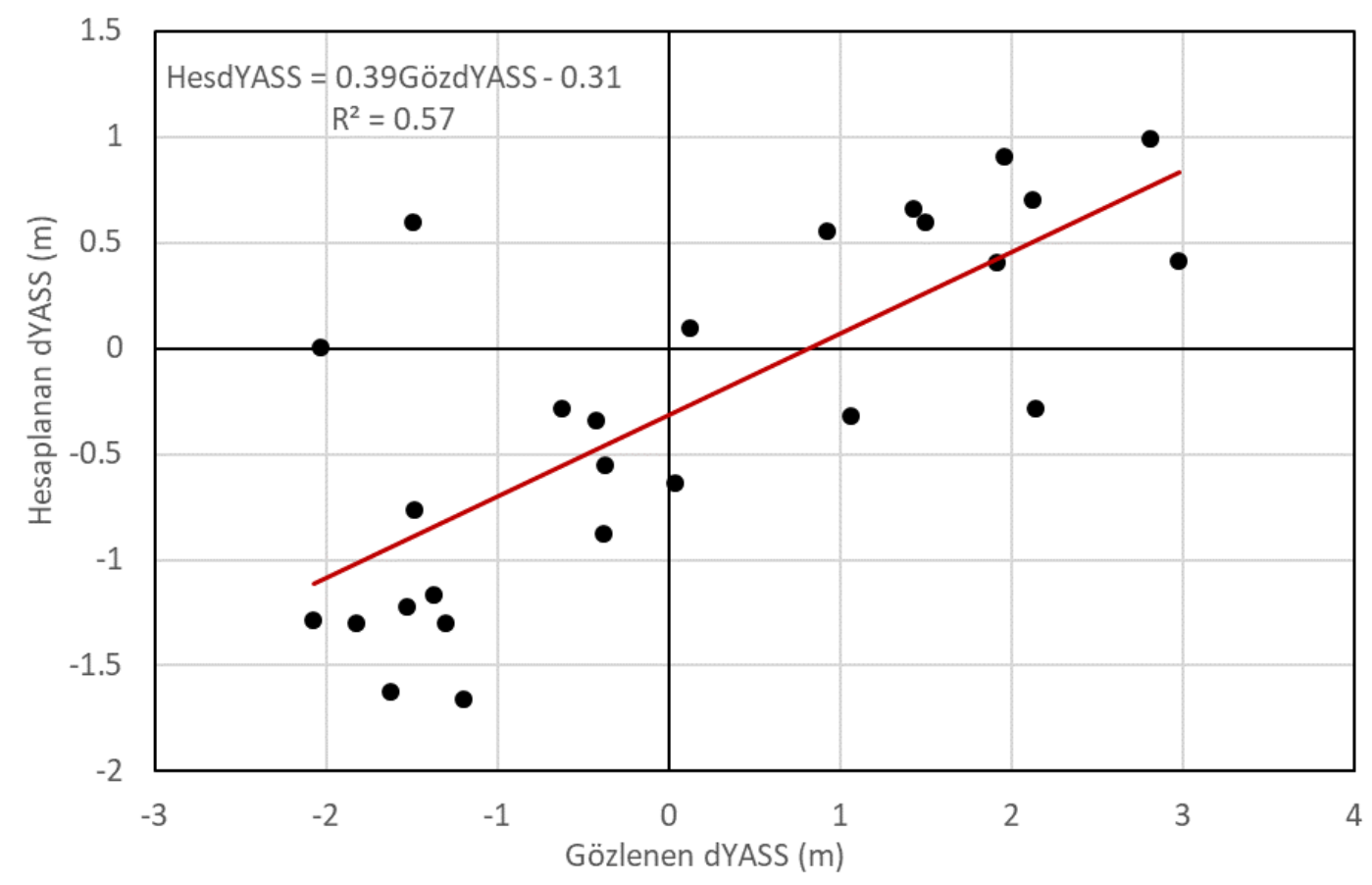

Şekil 11. 6512 nolu kuyu için dış etkilere kapalı sistem varsayımıyla OYES yöntemiyle türetilen yeraltısuyu seviyesi ile gözlenen seviye arasındaki ilişki.

Figure 11. Regression beween the observed and calculated groundwater levels for well no applying CRD for 6512 assuming a closed system. 
Yukarıda açıklanan analizler sonucunda, gözlenen yeraltısuyu seviyelerindeki dalgalanmalara sadece yağıştan süzülmeyle beslenmenin neden olmadığı, aynı zamanda dış etkenlerin bulunduğu sonucuna varılmıştır. Sulama mevsimini kapsayan kurak dönemlerde etkisi belirginleşen ve genellikle sulama amaçlı yeraltısuyu çekimleri yapay dış etken olarak dikkate alınmıştır. Benzer şekilde, özellikle yüksek miktarda yağışların olduğu dönemlerde yüzeysel akışa geçen suların dere yataklarından sızmayla yeraltısuyuna katılımları ise söz konusu dağınıklıklara neden olan doğal dış etkiler olarak değerlendirilmiştir.

\section{Pompaj ve Yüzeysel Akış Etkilerinin Yeraltısuyu Seviyesine Etkilerinin Analizi}

Yukarıda yapılan analizler ve değerlendirmeler sonucunda yeraltısuyu seviyesindeki dalgalanmaların salt "yağıştan doğrudan beslenme" etkisi altında olmadığı, özellikle yağışlı dönemlerde dere yataklarından sızma ve kurak dönemlerde pompaj gibi dış etkenlerden etkilendiği anlaşılmaktadır. Söz konusu dış etkilerin de değerlendirilmesi amacıyla OYES yöntemi pompaj ile boşalım ve dere yataklarından beslenmeyi de dikkate alacak şekilde yeniden uygulanmıştır. Bu uygulamada, eşitlik (7)'de yeralan ve pompaj etkisini tanımlayan terim, k>1 olarak alınmıştır. k, pompaj debisine ve akifer alanına bağlı olarak hesaplanmaktadır (bkz. eşitlik (9)).

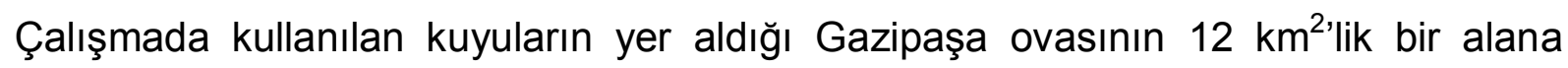
sahip Birinci Bölüm olarak tanımlanan kesiminde havzayı drene eden Bıçkıcı deresi akımları yağışı dönemlerde $5 \mathrm{~m}$ 3/s'den daha yüksek değerlere ulaşmaktadır. Olasılıkla dere yatağında su derinliği ve genişliği artmakta, dere yatağından sızma miktarı önemli oranlara yükselmektedir. Bu sızma, kuyudaki su seviyelerine yansımaktadır (Şekil 12). 


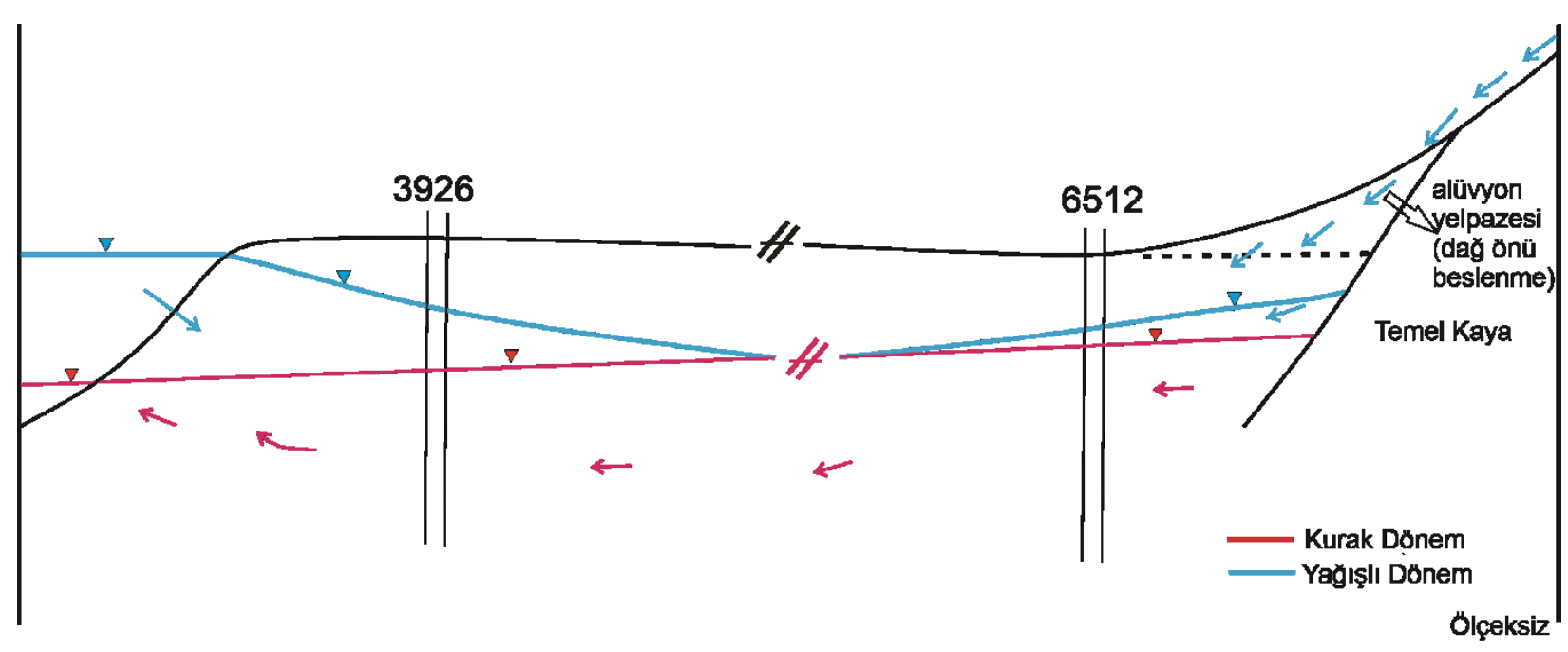

Şekil 12. 3926 ve 6512 nolu kuyuların hidrojeolojik konumları ve bu konumlarından dolayı yeraltısuyu seviyelerine beklenen etkileri gösteren şematik kesit.

Figure 12. A schematic cross-section depicting the expected effects on groundwater levels in wells 3926 and 6512 owing to their locations in the hydrogeologcial system.

Dere yatağından sızma miktarı ve etkinin kuyuya ulaşma süresi, etkinin yayılım hızını denetleyen hidrolik difüzyon katsayısına $(\omega)$ bağlıdır. İletimlilik katsayısının (T) depolama katsayısına (S) oranı şeklinde tanımlanan hidrolik difüzyon katsayısı Gazipaşa ovası akiferi için $6080 \mathrm{~m}^{2} / g u ̈ n$ ve $17770 \mathrm{~m}^{2} /$ gün olarak hesaplanmıştır. Hesaplamada, iletimlilik katsayısı değeri DSi (1973)'ten alınmıştır. DSi (1973), ayrıca, yeraltısuyu işletmesi yapılan kuyulardan çekilen yıllık toplam su miktarının $0.31 \times 10^{6} \mathrm{~m}^{3}$ dolayında olduğunu bildirmektedir.

3926 nolu kuyu, Bıçkıcı deresine yaklaşık 120 m uzaklıkta konumlandırılmıştır. Kuyuda gözlenen yeraltısuyu Bıçkıcı derenin yatağından ortalama 12-15 m daha düşük kottadır. Bu kuyuda gözlenen yeraltısuyu seviyelerinde meydana gelen değişimlerin taşkın dönemlerinde Bıçkıcı dereden etkilendiği, bu nedenle seviyede yağıştan doğrudan süzülmenin yarattığı yükselmeye ek olarak dere yatağından sızan suların da yaklaşık 2 aylık bir sürede gözlem kuyusunda ölçülen yeraltısuyuna ulaşması gerektiği anlaşılmaktadır. 6512 nolu kuyu ise, Bıçkıcı dereden yaklaşık 500 m uzaklıktadır. Bununla birlikte bu kuyu, ova düzlüğünün sınırında, topoğrafik yükselmenin başladığı alanda açılmıştır. Ova düzlüğünün sınırında çeşitli boyutlarda yelpaze oluşumu ile karşılaşılmaktadır. Yelpaze üzerinde veya yakınında 
konumlanan kuyularda yeraltısuyu seviyeleri yüzeysel akışa geçen suların doğrudan etkisi altında kalmaktadır (bkz. Şekil 12).

Öte yandan, akiferden pompajla su çekimi yapılan ve kurak döneme karşılık gelen yaz aylarında beklenen yeraltısuyu seviyesindeki düşüm, sadece yağışlardaki azalmaya bağlanamamaktadır (bkz. Şekil 8 ve Şekil 10). Ortalama yeraltısuyu seviyesinden negatif sapmaların bulunduğu kesimlerde korelasyonu düşüren bir dağınıklık gözlenmesi bu çıkarımı desteklemektedir (bkz. Şekil 9 ve Şekil 11). Gözlem kuyularında yeraltısuyu düşümü doğal koşullarda akifer karakteristikleri ve doğal boşalım alanının konumu ve türü (kaynak, baz akım vb) ile ilgilidir (Ekmekçi, 2015).

Dış etkilere açık sistem varsayımıyla 3926 ve 6512 nolu kuyularda yeraltısuyu seviyesinin ortalamadan sapma değerlerinin yüksek bir korelasyonla türetilebilmesi için yağışlı dönemlerde "dereden/yelpazeden beslenme" ve kurak dönemlerde "pompaj” miktarlarının aylara göre dağılımları Çizelge 7'de verilmiştir.

Çizelge 7'de verilen yağıştan doğrudan beslenme dışında dere yatağından ve/veya alüvyon yelpazesinden sızan su ile pompaj miktarı incelendiğinde aşağıdaki çıkarımlar yapılabilir. Beslenmenin kış ve ilkbahar aylarında gerçekleştiği, yağışların azaldığı ancak yüzeysel akışın yüksek olduğu Mayıs-Haziran aylarında da beslenmenin devam ettiği anlaşılmaktadır. Öte yandan, kurak aylar olan Ağustos, Eylül, Ekim ve Kasım aylarında ise pompaj etkisi görülmektedir. 3926 nolu kuyu için yapılan hesaplamalarda dere yatağından sızan su miktarının ortalama olarak $615 \mathrm{l} / \mathrm{s}$, pompaj/boşalım etkisini temsil eden miktarın ise ortalama $280 \mathrm{l} / \mathrm{s}$ dolayında olduğu ortaya çıkmaktadır. Bu değerler 6512 nolu kuyu için sırasıyla 1880 l/s ve 500 l/s dolayındadır. İki kuyu arasındaki bu önemli farklar, kuyuların hidrojeolojik konumlarıyla yakından ilgilidir. Kasım 1970 ayında meydana gelen yüksek yağış miktarına (136.8 mm) karşın yeraltısuyu seviyesinde yükselme bir yana düşümün devam etmesi hesaplamalarda dikkati çeken bir durum olmuştur. Bu durum, bir yandan yağışların etkisinin 2 ay gecikmeyle gözlenmesi, öte yandan çekim/boşalım etkisinin devam ettiği yönündeki değerlendirmeyi desteklemektedir. Benzer değerlendirme, Ekim 1971 ayı için de geçerlidir. Ekim 1971 ayında da yüksek yağış (141.9 mm) gerçekleşmiş, ancak bu yüksek yağışın yeraltısuyuna etki etmediği görülmektedir. Bu gözlemlere dayanarak, kurak aylarda anlık yüksek yağışların yeraltısuyu beslenmesine katkılarının olmadığı veya ihmal edilecek düzeyde olabildiği sonucuna varılabilir. 
Çizelge 7. Çalışmada kullanılan kuyularda, dış etkilere açık sistem varsayımıyla, gözlenen ve hesaplanan yeraltısuyu seviyelerinin ortalamadan sapması.

Table 7. Observed and calculated deviations of groundwater levels from the average for well no applying CRD for the wells used in this study assuming an open system.

\begin{tabular}{|c|c|c|c|c|c|c|c|c|c|}
\hline \multirow{2}{*}{ Aylar } & \multirow{2}{*}{$\begin{array}{l}\text { Yağıs } \\
(\mathbf{m m})\end{array}$} & \multicolumn{4}{|c|}{3926 nolu Kuyu } & \multicolumn{4}{|c|}{6512 nolu Kuyu } \\
\hline & & $\begin{array}{l}\text { dYASS } \\
\text { Gözlenen }\end{array}$ & $\begin{array}{c}\text { dYASS } \\
\text { Hesaplanan }\end{array}$ & $\begin{array}{l}\text { Sizma } \\
\left(m^{3} / a y\right)\end{array}$ & $\begin{array}{l}\text { Pompaj } \\
\left(\mathrm{m}^{3} / a y\right)\end{array}$ & $\begin{array}{c}\text { dYASS } \\
\text { Gözlenen }\end{array}$ & $\begin{array}{c}\text { dYASS } \\
\text { Hesaplanan }\end{array}$ & $\begin{array}{l}\text { Sizma } \\
\left(\mathrm{m}^{3} / a y\right)\end{array}$ & $\begin{array}{l}\text { Pompaj } \\
\left.\text { ( } m^{3} / a y\right)\end{array}$ \\
\hline Ekim 69 & 45.2 & -1.302 & -1.302 & & & -1.623 & -1.623 & & \\
\hline Kasım 69 & 99.7 & -0.312 & -0.445 & 120000 & & -0.383 & -0.878 & 90000 & \\
\hline Aralık 69 & 97.0 & -0.232 & -0.299 & 120000 & & -0.373 & -0.556 & 20000 & \\
\hline Ocak 70 & 45.4 & 1.488 & 1.175 & 1800000 & & 2.137 & -0.284 & 2700000 & \\
\hline Şubat 70 & 181.0 & 0.758 & 0.758 & 4000000 & & 1.917 & 0.408 & 40000000 & \\
\hline Mart 70 & 56.3 & 1.878 & 1.488 & 1800000 & & 2.977 & 0.409 & 3500000 & \\
\hline Nisan 70 & 74.4 & 2.398 & 2.233 & 2400000 & & 2.807 & 0.989 & 2900000 & \\
\hline Mayıs 70 & 9.5 & 1.298 & 1.378 & 1500000 & & 2.127 & 0.699 & 2500000 & \\
\hline Haziran 70 & 11.4 & 1.278 & 0.264 & & & 1.957 & 0.906 & 1700000 & \\
\hline Temmuz 70 & & 0.298 & -0.288 & & & 1.067 & -0.317 & 1700000 & \\
\hline Ağustos 70 & 2.4 & -0.382 & -0.433 & & & 0.037 & -0.638 & & \\
\hline Eylül 70 & & -0.452 & -0.672 & & & -1.373 & -1.168 & & -1050000 \\
\hline Ekim 70 & & -1.442 & -1.459 & & -950000 & -1.523 & -1.219 & & -1200000 \\
\hline Kasım 70 & 136.8 & -0.832 & -0.925 & & -240000 & -1.823 & -1.300 & & -1600000 \\
\hline Aralık 70 & 48.7 & -0.402 & -0.732 & & & -1.303 & -1.300 & & -1100000 \\
\hline Ocak 71 & 82.6 & -0.102 & -0.299 & & & -0.423 & -0.342 & & \\
\hline Şubat 71 & 137.3 & -0.902 & -0.902 & & & -2.033 & 0.006 & & \\
\hline Mart 71 & 57.6 & -0.522 & -0.560 & & & -1.493 & 0.595 & & -950000 \\
\hline Nisan 71 & 67.6 & 0.898 & 0.930 & 1000000 & & 1.497 & 0.598 & 1000000 & \\
\hline Mayıs 71 & 73.1 & 0.748 & 0.154 & & & 1.427 & 0.662 & 1400000 & \\
\hline Haziran 71 & 3.6 & 0.298 & 0.106 & & & 0.927 & 0.555 & 1000000 & \\
\hline Temmuz 71 & 1.2 & -0.002 & -0.101 & & & 0.127 & 0.097 & & \\
\hline Ağustos 71 & & -0.482 & -0.677 & & -500000 & -0.623 & -0.288 & & -470000 \\
\hline Eylül 71 & 15.2 & -0.862 & -0.971 & & -600000 & -1.483 & -0.762 & & -800000 \\
\hline Ekim 71 & 141.9 & -1.302 & -1.368 & & -800000 & -2.073 & -1.283 & & -1800000 \\
\hline Kasım 71 & 28.1 & -1.822 & -1.692 & & -1250000 & -1.200 & -1.657 & & -2700000 \\
\hline
\end{tabular}

Bu çıkarımlar, gerek gözlem kuyusu için en uygun yer seçiminde, gerekse gözlem yapılmakta olan kuyulardan elde edilen verilerin değerlendirilmesinde dikkate alınması gereken hidrojeolojik koşulların önemini ortaya koymaktadır. Hidrojeolojik konumları nedeniyle yeraltısuyu seviyeleri açısından yağışa ve dış etkilere farklı tepkiler veren kuyuların hidrojeolojik kavramsallaştırma ve karakterizasyon çalışmalarında bu yönleriyle değerlendirilmeleri büyük bir önem taşımaktadır.

3926 nolu kuyu için, yağışlı dönemde akarsudan beslenme, kurak dönemlerde ise pompaj etkisi dikkate alınarak tekrarlanan OYES analizleri ile elde edilen sonuçlar Şekil 13'te gösterilmiştir. Hesaplamalar sonucunda elde edilen yeraltısuyu seviyesindeki değişimin gözlenen değişimlerle uyumunda, Şekil 8'de verilenle karşılaştırıldığında yüksek düzeyde bir düzelme olduğu görülmektedir. Söz konusu uyumun düzeyi sayısal olarak gözlenen değerler ile hesaplanan değerler arasındaki korelasyonla ortaya konmuştur. Şekil 14'te verilen regresyon grafiğinde 
determinasyon katsayısının $\mathrm{R}^{2}=0.94$ 'e, Pearson korelasyon katsayısının r=0.97'ye yükseldiği görülmektedir. Şekil 14'te özellikle, pompaj etkisinin yansıtıldığı kurak dönemi temsil eden negatif sapma kesiminde düzelme dikkati çekmektedir. Regresyon doğrusunun 1:1 doğrusuna yakın (eğim=0.98) olması söz konusu korelasyonun gözlenen değer ile hesaplanan değer arasındaki yüksek uyumun yanı sıra değerlerin de birbirine yakın olduklarını göstermektedir.

Benzer hesaplamalar 6512 nolu kuyu için gerçekleştirilmiş ve yağışlı dönemde alüvyon yelpazesinden/dere yatağından beslenme, kurak dönemlerde ise boşalım/pompaj etkisi dikkate alınarak tekrarlanan OYES analizleri ile elde edilen sonuçlar Şekil 15’te gösterilmiştir. Dış etkilere açık sistem varsayımıyla yapılan hesaplamalarla türetilen yeraltısuyu seviyesindeki değişimin gözlenen değişimlerle uyumunda, Şekil 10'da verilene e kıyasla çok ileri düzeyde bir düzelme olduğu görülmektedir. Uyum düzeyinin sayısal olarak ortaya konması amacıyla gerçekleştirilen regresyon analizi Şekil 16'da gösterilmiştir. Şekilde verilen regresyon grafiğinde determinasyon katsayısının $\mathrm{R}^{2}=0.97$ 'ye, Pearson korelasyon katsayısının r=0.98'e yükseldiği görülmektedir.

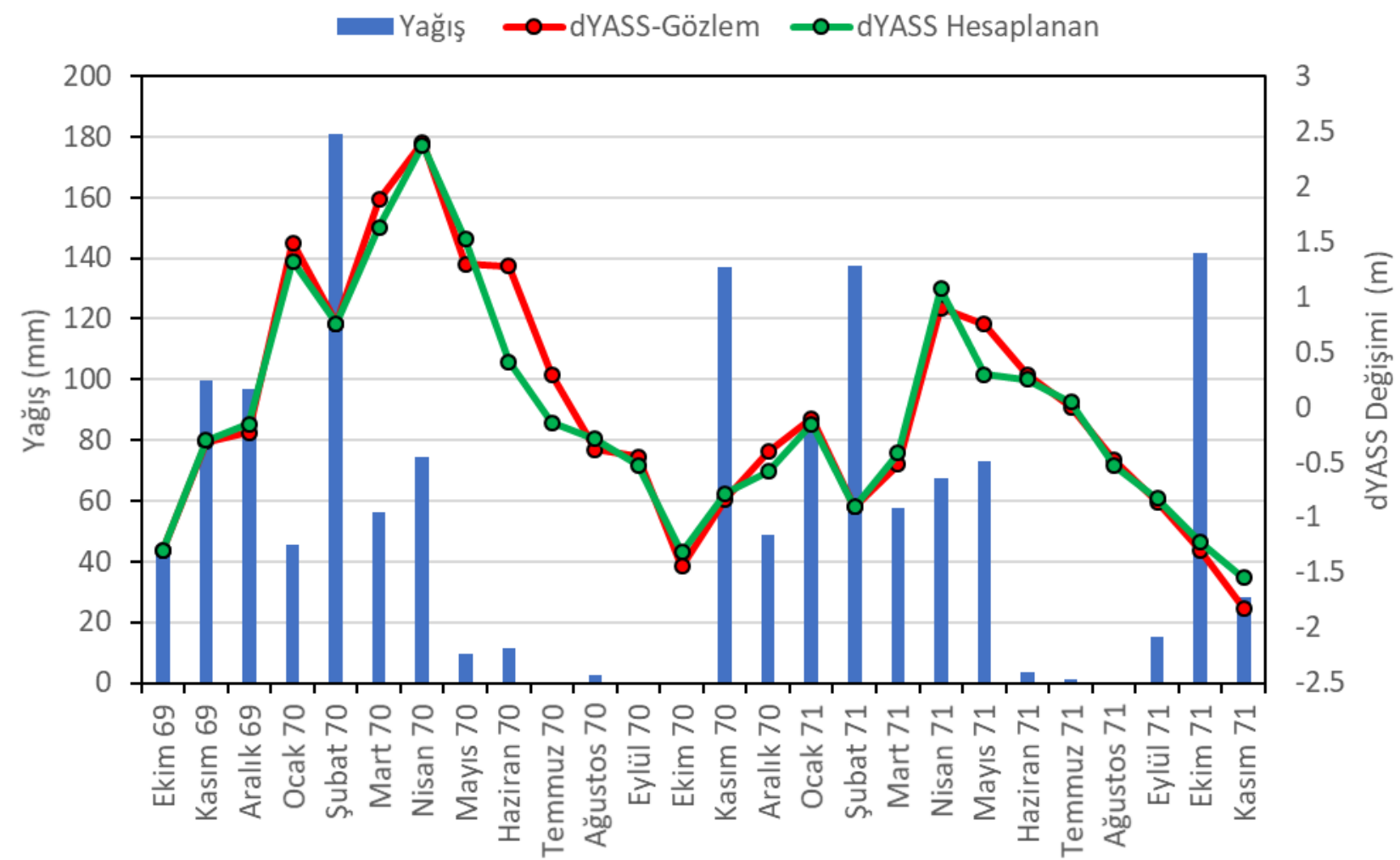

Şekil 13. OYES yöntemiyle pompaj ve dereden beslenme gibi dış etkilere açık sistem varsayımıyla 3926 nolu kuyu için hesaplanan ve gözlenen yeraltısuyu seviyesi dalgalanmaları.

Figure 13. Observed and calculated groundwater levels for well no applying CRD for 3926 assuming an open system affected by external factors such as pumping and percolation through river bed. 


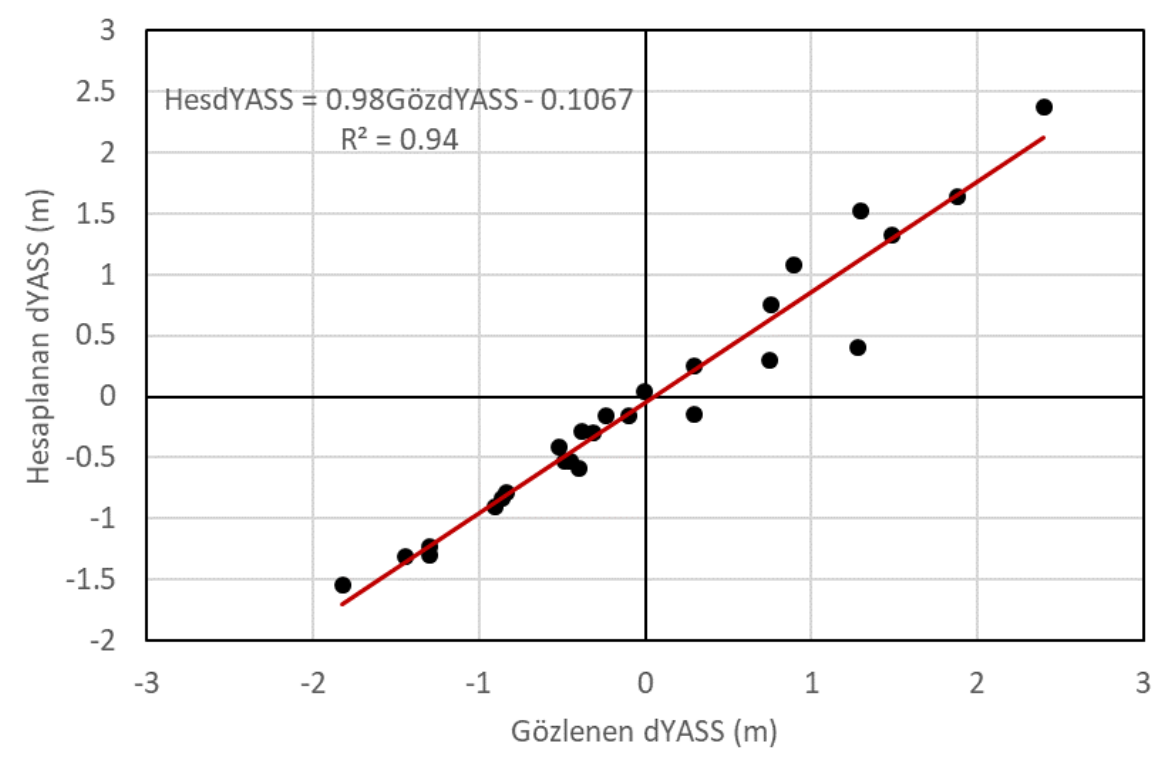

Şekil 14. OYES yöntemiyle pompaj ve dereden beslenme gibi dış etkilere açık sistem varsayımıyla 3926 nolu kuyu için hesaplanan ve gözlenen yeraltısuyu seviyesi dalgalanmaları arasındaki korelasyon.

Figure 14. Regression between observed and calculated groundwater level fluctuations in well no 3926, assuming an open system affected by external factors such as pumping and percolation through river bed.

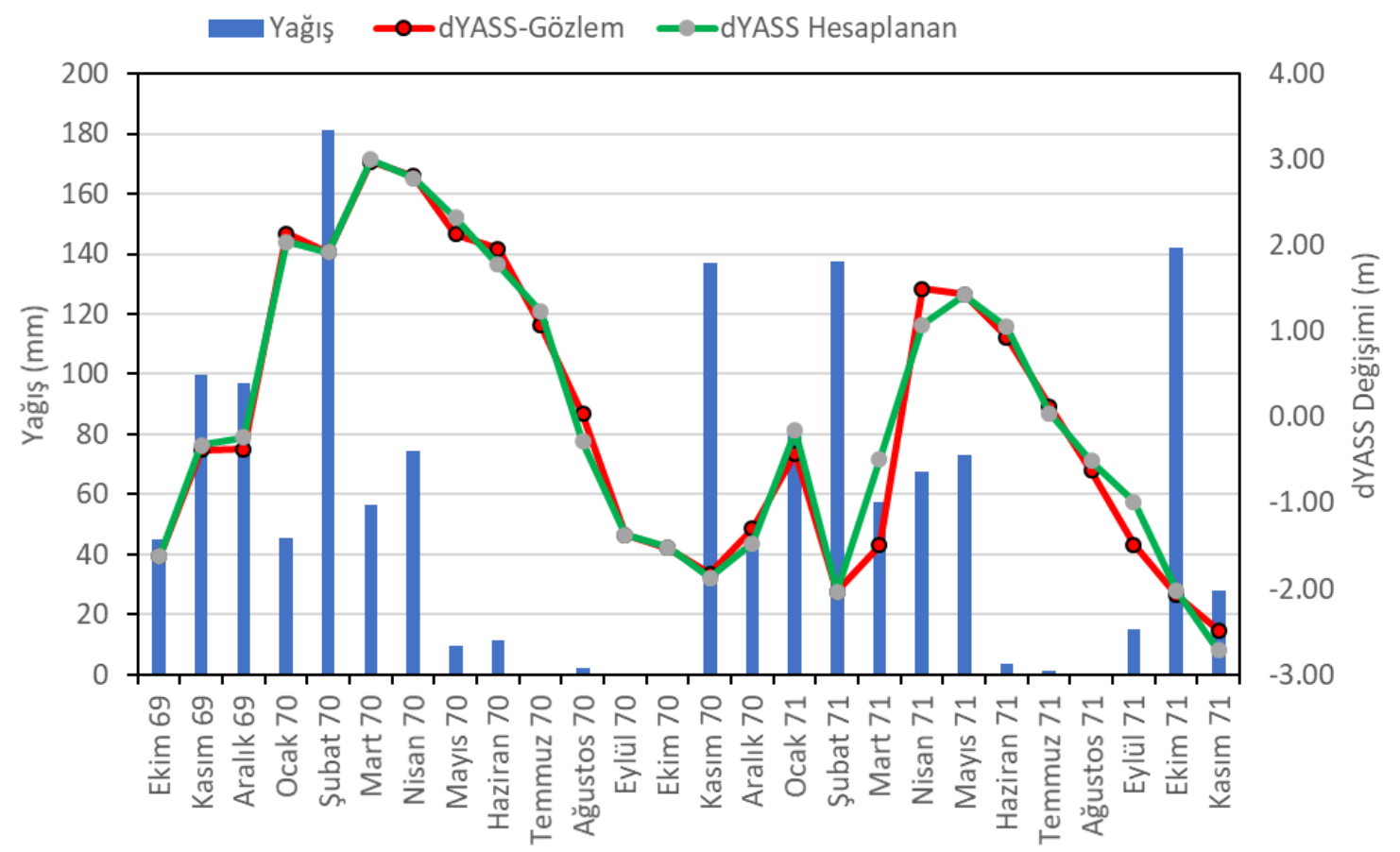

Şekil 15. OYES yöntemiyle pompaj ve dereden beslenme gibi dış etkilere açık sistem varsayımıyla 6512 nolu kuyu için hesaplanan ve gözlenen yeraltısuyu seviyesi dalgalanmaları.

Figure 15. Observed and calculated groundwater level fluctuations in well no 6512, assuming an open system affected by external factors such as pumping and percolation through river bed. 


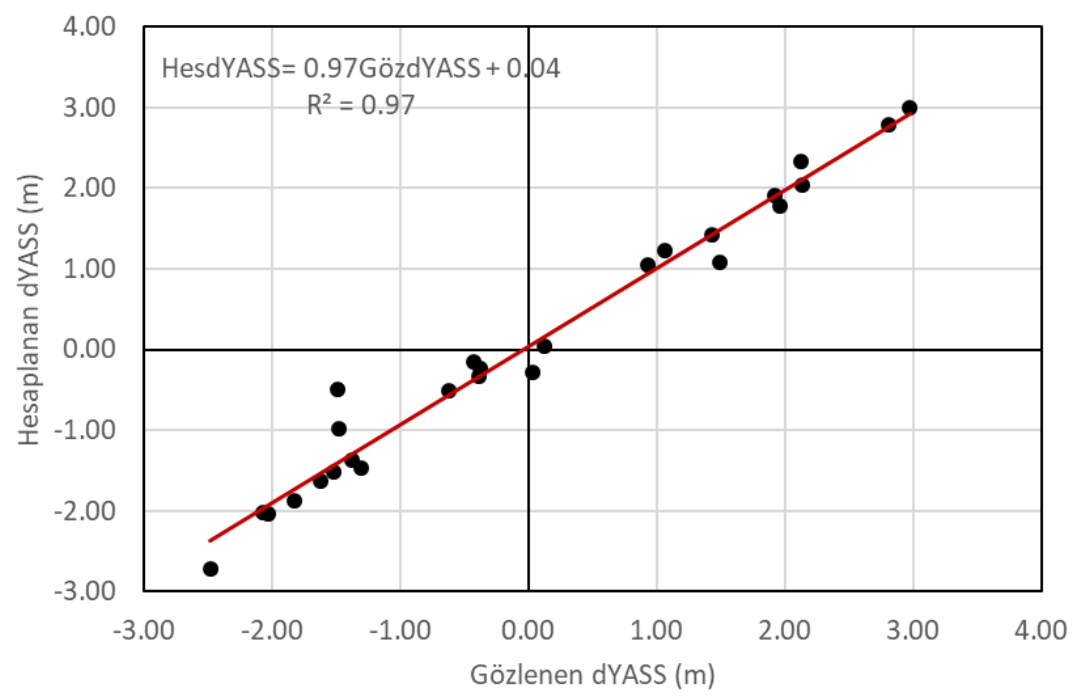

Şekil 16. OYES yöntemiyle pompaj ve dereden beslenme gibi dış etkilere açık sistem varsayımıyla 6512 nolu kuyu için hesaplanan ve gözlenen yeraltısuyu seviyesi dalgalanmaları arasındaki korelasyon.

Figure 16. Regression between observed and calculated groundwater level fluctuations in well no 6512, assuming an open system affected by external factors such as pumping and percolation through river bed.

Regresyon doğrusunun 1:1 doğrusuna yakın (eğim=0.98) olması söz konusu korelasyonun gözlenen değer ile hesaplanan değer arasındaki uyumun yanı sıra değerlerin de birbirine yakın olduklarını göstermektedir. 3926 nolu kuyudaki durumdan farklı olarak, Şekil 16'da verilen grafiğin negatif sapmaların yeraldığı kesimde dağınıklığın daha yüksek oranda olduğu görülmektedir. Bu durum, 6512 nolu kuyuda pompaj etkisinin, kuyunun konumu nedeniyle daha karmaşık süreçlere bağlı olduğu şeklinde değerlendirilebilir.

\section{Yılık Beslenme Miktarının Kestirimi}

Yeraltısuyu seviyesindeki değişimlere neden olan dış etkilerin de dikkate alınması, yağıştan doğrudan beslenme miktarının daha gerçekçi bir şekilde belirlenebilmesini sağlamaktadır. Bu çalışmada yeraltısuyu seviyeleri Gazipaşa Meteoroloji İstasyonunda kaydedilen yağışlarla birlikte analiz edilen 3926 ve 6512 nolu gözlem kuyuları için yapılan hesaplamalar, eşitlik (10)'dan yararlanılarak beslenme hesabında kullanılmıştır. Aylık ölçekte hesaplanan beslenme miktarı, aylık toplam 
yağışlarla Şekil 17 'de gösterilmiştir. Şekilde verilen sütun grafikte, toplam aylık yağışlar ile beslenme miktarı arasında doğrusal bir ilişkinin bulunmadığı görülmektedir. Bu durum 2 temel nedenden kaynaklanmaktadır: 1) yağışların doygun zona ulaşması için geçen süre (gecikme süresi=2 ay), 2) beslenmeye etki eden yağış döneminin 3 ay sürmesi (kısa dönem hafıza etkisi).

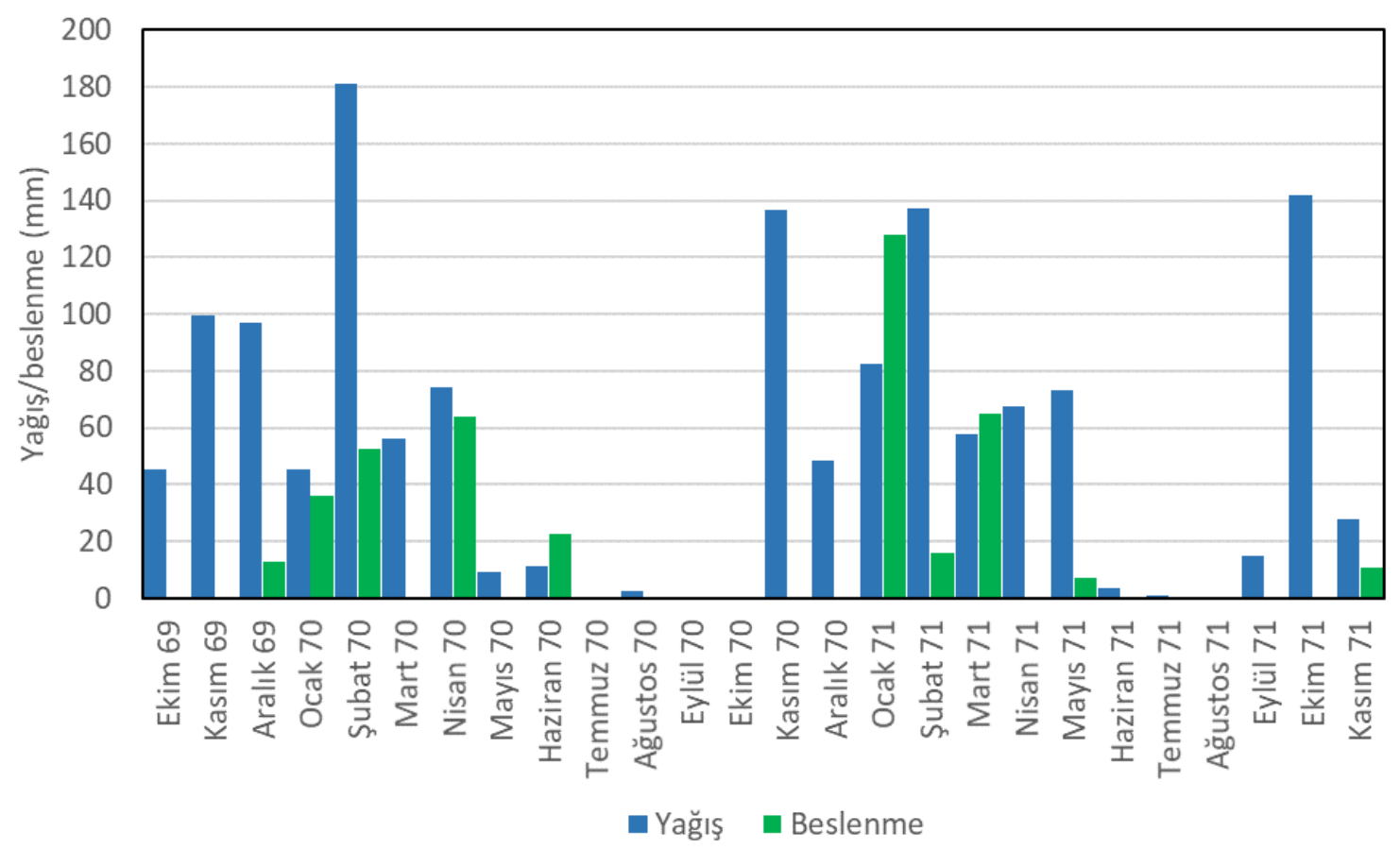

Şekil 17. Çalışma alanında yağıştan doğrudan beslenme miktarı ve toplam yağışların aylara göre dağılımı.

Figure 17. Distribution of monthly total rainfall and the calculated direct recharge from rainfall in the study area.

OYES yaklaşımında, gecikmenin olmadığı (gecikme süresi 0 ay) ve beslenmenin sadece ilgili ayda düşen yağıştan gerçekleştiği (kısa dönem hafıza = 1 ay) duruma uygun sistemlerde, beslenme ile toplam yağışlar arasında daha yüksek bir korelasyon elde edilebilir. Yeraltısuyu seviyelerindeki değişimlerin ortalama yağıştan eklenik sapmadan yola çıkılarak türetildiği OYES yaklaşımında, gecikme süresi ile beslenme dönemi uzunluğu optimizasyonuyla, incelenen yeraltısuyu sisteminin dış etkilere açık olup olmadığı, beslenmede etkili olan yağışlar ile yağışların doygun zona ulaşma süreleri ile ilgili değerlendirmeleri yapmak mümkün olabilmektedir. Bu değerlendirmeler, yeraltısuyu sistemine ait hidrojeolojik kavramsal modelin temsil edici olma niteliğini artıracak bilgiler sağlamaktadır. 
Çalışma alanı için yapılan beslenme miktarı hesaplamaları sonucunda 1970 su yılında toplam yağış $622.3 \mathrm{~mm}$, yıllık toplam beslenme miktarı ise $108 \mathrm{~mm}$ bulunmuştur. 1971 su yılı için toplam yıllık yağış $623.7 \mathrm{~mm}$, yıllık toplam beslenme miktarı ise $113.5 \mathrm{~mm}$ olarak hesaplanmıştır. Aylık ölçekte, değişeceği gözönünde bulundurularak, bu değerlere göre yağıştan yıllık beslenmenin, 1970 ve 1971 su yılları için toplam yağışın sırasıyla \%17.4 ve \%18.2'i (ortalama \% 17.8) oranında gerçekleştiği anlaşılmaktadır.

Bu değer, DSi (1973) tarafından yeraltısuyu bütçesi hesaplamalarında kullanılan Thorthwaite-Mather yöntemiyle elde edilen değerden $(182 \mathrm{~mm} / \mathrm{yıl})$ ortalama \% 40 oranında daha düşüktür.

\section{SONUÇLAR}

Yeraltısuyu kaynakları potansiyelinin yıllık değişiminin belirlenmesinde ihityaç duyulan yağıştan doğrudan beslenme miktarının kestirilmesi, mevcut yöntemlerin içerdiği belirsizlikler nedeniyle hidrojeoloji mühendisliğinin en güç konularından biridir. Yeraltısuyu seviyesinin su yılı boyunca değişiminden yararlanan hesaplama yöntemlerinin temelinde bulunan akiferin "dış etkilerden bağımsız, kapalı bir sistem olarak davrandığı" geçerliliği doğal sistemlerde genellikle sorgulanabilir bir varsayımdır. Bu nedenle, bu tür hesaplamalarda öncelikle gözlenen yeraltısuyu seviyelerinin yağış, akarsu yataklarından sızma gibi beslenme ve doğal ve/veya pompajla boşalım ile olan ilişkilerinin irdelenmesi gerekmektedir. Kısaca ortalama yağıştan eklenik sapma olarak adlandırılan yaklaşımla, öncelikle yağışların yeraltısuyu seviye değişimine olan etkileri dikkate alınarak yeraltısuyu seviyelerindeki sapmaların türetilebileceği ortaya konmuştur. Bu şekilde türetilen yeraltısuyu seviye değişimleri ile gözlenen yeraltısuyu seviye değişimleri arasındaki korelasyon düzeyine bağlı olarak incelenen yeraltısuyu sisteminin dış etkilere açık veya kapalı olma durumu tanımlanabilmektedir. Açık sistem olması durumunda, bu yaklaşımla gözlenen yeraltısuyu seviye değişimlerinin yüksek korelasyonla türetilebilmesi ve dış etkilerin düzeyinin tahmin edilebilmesi mümkün olmaktadır. Yeraltısuyu seviyesindeki değişim, aynı zamanda doygun zondaki hacim değişimi anlamına geldiğinden, akifer 
alanı ve depolama katsayısı/özgül verim değerlerinden yağışların doygun zona kattığı su hacminin de hesaplanması olanaklıdır. Bu şekilde, aylık veya yıllık toplam yağışlardan meydana gelen beslenme hesaplanabilmektedir. Yöntem, yağışların doygun zona ulaşma süresi olarak tanımlanabilecek "gecikme süresi" ve "beslenmenin geriye doğru hangi yağışların etkisinde kaldığı" (beslenme dönemi-kısa dönem hafıza) konusunda da değerlendirme yapma olanağı vermektedir.

Antalya-Gazipaşa ovası akiferinde DSi tarafından izlenen iki gözlem kuyusu verileri kullanılarak uygulanan yaklaşımla gözlenen yeraltısuyu seviye değişimleri \%98'lik bir korelasyonla yağışlardan itibaren türetilebilmiştir. Yapılan optimizasyon ile Gazipaşa ovası akiferinin, gerek dere yatağından/alüvyon yelpazesinden sızma, gerekse doğal boşalım/pompajla çekim gibi dış etkiler nedeniyle bir açık sistem oluşturduğu sonucuna varılmıştır. Benzer şekilde, yağışların yeraltısuyu seviyelerine etkileri 2 ay gecikmeyle gerçekleşmekte ve beslenme geriye doğru 3 aylık dönemde meydana gelen yağışlardan kaynaklanmaktadır. Yıllık beslenme miktarı ise toplam yıllık yağışların \% 18'i oranında gerçekleşmektedir. DSi (1973)'e göre yağıştan doğrudan beslenme toplam yağışın yaklaşık \% 25’i kadardır. İki yöntem arasındaki fark \% 40 düzeyindedir.

Örnek uygulamada, ortalama yağışlardan eklenik sapma yöntemi uygulandığında, beslenme miktarının tahmin edilmesinin yanı sıra akiferin ortalama özgül verimi, yeraltısuyu sisteminin sınır koşulları ve hidrojeolojik davranışı ile dış etkilere karşı tepkilerinin şiddeti ve zamanı ile ilgili olarak da önemli bilgiler elde edilebilmektedir. Bu bilgiler ışığında, iklim değişiklikleri ve/veya yeraltısuyu işletmeleri nedeniyle pompaj programında yapılacak değişikliklerin yeraltısuyu sisteminde yaratacağı birleşik etkilerin kestirilmesi söz konusu olabilmektedir.

\section{TEŞEKKÜR}

Yapıcı eleştirilerini hızlı bir şekilde sağlayan hakemler değerli görüş ve önerileriyle makalenin anlaşılabilirliğini arttırmışlardır. Yazarlar, bu katkıları nedeniyle hakemlere, ve basım sürecinde yardım ve çabalarını esirgemeyen Editör Sayın Prof. Dr. M. Tekin YÜRÜR ile Teknik Editör Sayın Dr. Gülbanu TEKBULUT’a teşekkür ederler. 


\section{KAYNAKLAR}

Bear, B., 1979. Hydraulics of Groundwater. McGraw-Hill, Inc., New York.

Beekman H.E, Xu Y. 2003. Review of groundwater recharge estimation in arid and semi-arid southern Africa. In: Xu Y and Beekman HE (eds.) Groundwater Recharge Estimation in Southern Africa. UNESCO International Hydrological Programme, Paris.

Botha L.J., and Bredenkamp, D.B., 1993. Lichtenburg: a case study incororating the cumulative rainfall departures. Technical Report, Directorate Geohydrology, Dept. of Water Affairs, Pretoria.

Bozan Ç., 2018. Gazipaşa Kıyı Ovasının Hidrojeolojik İncelemesi. Yüksek Lisans Tezi, Hacettepe Üniversitesi, Ankara (yayımlanmamış).

Bredenkamp, D.B., Botha, L.J., Van Tonder, G.J. and Van Rensburg, H.J. 1995. Manual on quantitative estimation of groundwater recharge and aquifer storativity: Based on practical hydro-logical methods. Water Research Commission, rapor no. 353. Pretoria, İngilizce. DSi, 1973. Gazipaşa Ovası hidrojeolojik etüt raporu. Ankara (yayımlanmamış).

DSi, 1964. Devlet Su İşleri Genel Müdürlüğü, Gazipaşa Ovası rezerv raporu, Ankara (yayımlanmamış, Türkçe).

DSi, 1973. Devlet Su İşleri Genel Müdürlüğü, Gazipaşa Ovası hidrojeolojik etüt raporu. Ankara (yayımlanmamış, Türkçe).

Ekmekçi, M., 2015. Yeraltısuyu potansiyelinin belirlenmesi: Su bilançosu yaklaşımları. DSi Jeoteknik ve Yeraltısuları Dairesi Başkanlığı Yeraltısuları Semineri, İstanbul.

Freeze, R. A., Cherry, J.A., 1979. Groundwater. Prentice-Hall, NJ.

Gieske A., 1992. Dynamics of Groundwater Recharge, Ph. D. Thesis, Free University, Amsterdam (yayımlanmamış).

Jacob, C.E., 1944. Correlation of groundwater levels on Long Island, New York. Transactions American Geophysical Union, Vol. 25, 928-939.

Keleş, A., 1996. Gazipaşa (Antalya) Ovası hidrojeoloji incelemesi, Yüksek Lisans Tezi, Süleyman Demirel Üniversitesi, Isparta (yayımlanmamış). 
Kinzelbach, W., Aeschbach, W., Alberich, C., Goni, I.B., Beyerle U., Brunner, P., Chiang, W-H., Rueedi, J. and Zoellmann, K., 2002. A Survey of methods for groundwater Recharge in arid and semi-arid regions. Early Warning and Assessment Report Series, UNEP/DEWA/RS.02-2. United Nations Environment Programme, Nairobi, Kenya.

Korkmaz, N., 1978. Akiferlerde su seviye rasatlarından faydalanılarak boşalım katsayısının hesaplanması. Devlet Su İşleri Genel Müdürlüğü, Ankara (yayımlanmamış).

Lerner, D.N., Issar, A.S., Simmers, I. 1990. Groundwater Recharge, IAH, International Contributions to Hydrogeology, 8, Verlag Heinz Heise, Hannover.

Sharma, M.L., 1989. Groundwater Recharge. Balkema, Rotterdam.

Simmers, I., 1988. Estimation of Natural Groundwater Recharge. D. Reidel Publishing Company, Dordrecht.

Sun, X., Xu, Y., Jovanovic, N.Z., Kapangaziwiri, E., Brendonck, L., Bugan, R.D.H., 2013, Application of the rainfall infiltration breakthrough (RIB) model for groundwter recharge estimation in most coastal South Africa. WaterSA, Vol. $39(2)$

Şen. Z., 2019. Groundwater recharge level estimation from rainfall record probability match methodology. Earth Systems and Environment, 3, 603-612.

Todd, D. K., 1980. Groundwater Hydrology. John Wiley\&Sons, New York.

$\mathrm{Xu}, \mathrm{Y}$. and Van Tonder, G.J., 2001. Estimation of recharge using a revised CRD method. Water SA, Vol.27, No. 3, 341-343.

Wenzel, L.K., 1936. Several methods of groundwater levels. Transactions American Geophysical Union, Vol.17, 400-405. 